Supporting Information for:

\title{
Iterative Exponential Growth Synthesis and Assembly of Uniform Diblock Copolymers
}

\author{
Yivan Jiang, Matthew R. Golder, Hung V.-T. Nguyen, Yufeng Wang, Mingjiang \\ Zhong, Jonathan C. Barnes, Deborah J. C. Ehrlich, Jeremiah A. Johnson* \\ Department of Chemistry, Massachusetts Institute of Technology, Cambridge, Massachusetts 02139 \\ *jaj2109@mit.edu
}




\section{Table of Contents}

Section A. Materials / General Methods / Instrumentation $\quad$ S4

\begin{tabular}{l|r} 
Section B. Synthetic Protocols & S5
\end{tabular}

1) $R-(-)-G P E$

2) Monomer 1-alkyne
a) RI
b) $R 2$
c) $R 3$
d) $R 4$
e) 1-alkyne

3) Monomer $1-N_{3}$
a) $R 5$
b) R6
c) $1-N_{3}$

4) Allyl-IEG generations
a) G1-Dimer (2)
b) G2-Tetramer (4)
c) G3-Octamer (8)
d) G4-Hexadecamer (16)

5) Thiol-ene functionalization of allyl-IEG 16-mer
a) $16 \boldsymbol{b}$ - Capping the terminal alkyne with $\mathrm{MeBz} \mathrm{N}_{3}$
b) 16- $\left(C_{10}\right)-N_{3}-$ Azidification and Thiol-ene reaction

6) Synthesis of diblock copolymers
a) 32a-Coupling 16-alkyne with 16-( $\left.C_{10}\right)-N_{3}$
b) 32TEG
c) $32 T G$
d) Acetyl32TG 
Section C. Spectroscopic Characterization

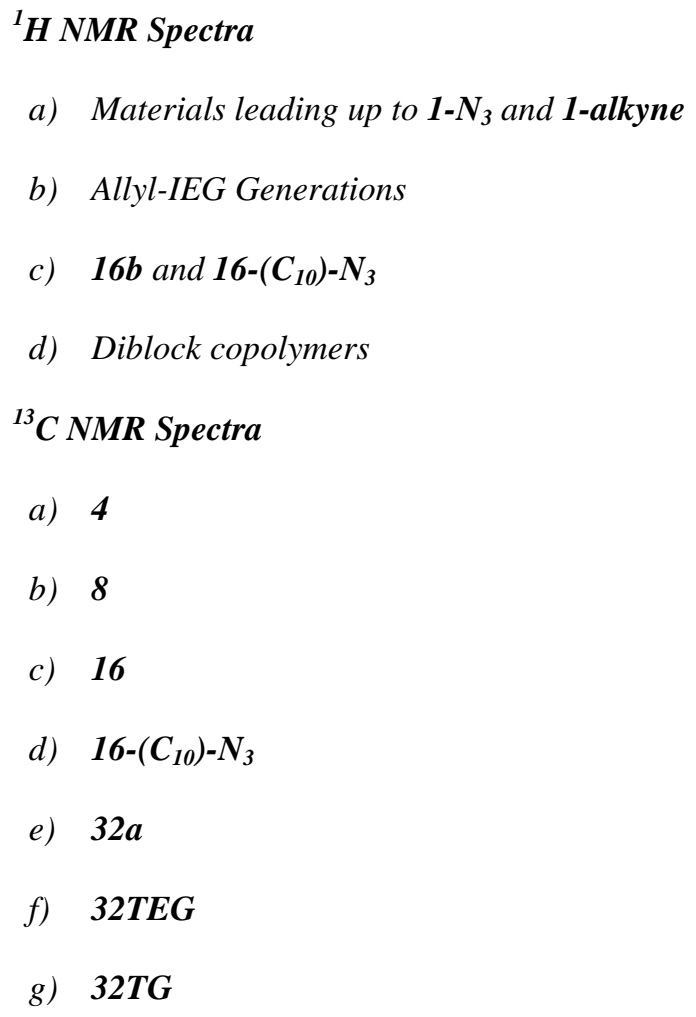

Section D. Spectrometric Characterization

Matrix-Assisted Laser Desorption/Ionization Time-of-Flight Mass Spectrometry (MALDI-TOF-MS)
a) 4,8 , and 16
b) 32a, 32TEG, 32TG

Section E. Extended Gel Permeation Chromatography Traces
a) $2,4,8$, and 16
b) 32a, 32TEG
c) 32TG
d) Acetyl32TG

Section F. Thermal Characterization 


\section{Section A. Materials / General Methods / Instrumentation}

All reagents were purchased from commercial suppliers and used without further purification unless stated otherwise. Gel permeation chromatography (GPC) analyses were performed on an Agilent 1260 Infinity setup with two Shodex KD-806M columns in tandem and a $0.025 \mathrm{M} \mathrm{LiBr}$ DMF mobile phase run at $60{ }^{\circ} \mathrm{C}$. The differential refractive index (dRI) of each compound was monitored using a Wyatt Optilab T-rEX detector. Column chromatography was carried out on silica gel 60F (EMD Millipore, 0.040-0.063 mm). Nuclear magnetic resonance (NMR) spectra were recorded on Varian Inova-500 spectrometers, with working frequencies of $500\left({ }^{1} \mathrm{H}\right)$ and 125 $\left({ }^{13} \mathrm{C}\right) \mathrm{MHz}$. Chemical shifts are reported in ppm relative to the signals corresponding to the residual non-deuterated solvents: $\mathrm{CDCl}_{3}, \delta \mathrm{H}=7.26 \mathrm{ppm}$ and $\delta \mathrm{C}=77.16 \mathrm{ppm} ;\left(\mathrm{CD}_{3}\right)_{2} \mathrm{SO}, \delta \mathrm{H}=2.50 \mathrm{ppm}$. High-resolution mass spectra (HRMS) were measured on a Bruker Daltonics APEXIV 4.7 Tesla Fourier Transform Ion Cyclotron Resonance Mass Spectrometer (FT-ICR-MS) using an electrospray ionization (ESI) source. Matrix-assisted laser desorption/ionization-time of flight (MALDI-TOF) mass spectra were obtained on a Bruker model MicroFlex instrument using $\alpha$-cyano-4-hydroxycinnamic acid as the matrix. Thermal characterization of all 5 th generation polytriazoles (32-mers) was carried out using thermogravimetric analysis (TGA) on a TA Instruments Discovery TGA. Samples were run in platinum TGA pans at a ramp rate of $10{ }^{\circ} \mathrm{C}$ per minute from 50 to $600{ }^{\circ} \mathrm{C}$. Differential scanning calorimetry (DSC) was performed on a TA Instruments Discovery DSC, where each sample was run with a Tzero aluminum pan sealed with a hermetic lid. Determination of the glass transition temperature was taken from the $3^{\text {rd }}$ heating cycle of a run where the sample was cycled at a rate of $10{ }^{\circ} \mathrm{C}$ per minute from -50 to $175^{\circ} \mathrm{C}$. Small angle X-ray scattering (SAXS) data were collected at beamline 12-ID-B at the Advanced Photonic Source (APS) at Argonne National Laboratory. The energy of the beam was $14 \mathrm{keV}$, which corresponds to a wavelength of 0.08857 nm. All SAXS samples were loaded into the center of Bokers aluminum washers $(0.900 \pm 0.005$ ” OD x $0.079 \pm$ 0.005 " ID) with $0.40 \pm 0.04$ ” thickness. SAXS, TEM, and AFM samples were prepared by drop-casting by a 20 $\mathrm{mg} / \mathrm{mL}$ dichloromethane (DCM) solution of the desired polymer. For all samples, the DCM was evaporated at ambient temperature, the samples were annealed at $120{ }^{\circ} \mathrm{C}$ under vacuum for $2 \mathrm{~h}$, and then they were allowed to cool to room temperature overnight under reduced pressure (ca. 100 mTorr). 


\section{B. Synthetic Protocols}

\section{1) $(\boldsymbol{R})-G P E$}

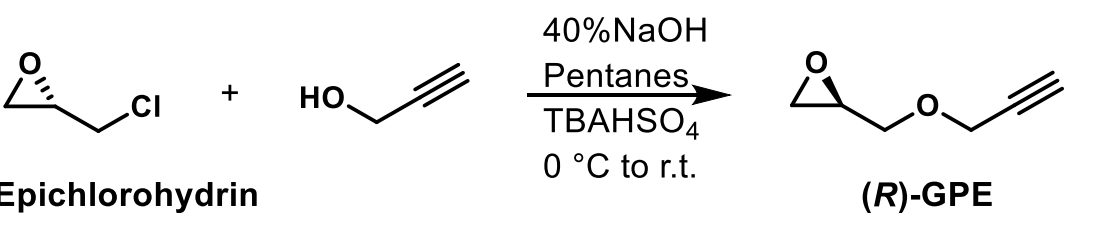

(R)-GPE: A 40\% $\mathrm{NaOH}$ aqueous solution was prepared by dissolving $226 \mathrm{~g}$ of $\mathrm{NaOH}$ in $340 \mathrm{~mL} \mathrm{H}_{2} \mathrm{O}$. Then, propargyl alcohol $(30.3 \mathrm{~mL}, 540 . \mathrm{mmol})$ was added to the stirring $\mathrm{NaOH}$ solution at $0{ }^{\circ} \mathrm{C}$. This reaction mixture was allowed to stir for $\sim 30$ min before a solution containing tetrabutylammonium hydrogensulfate $\left(\mathrm{TBAHSO}_{4}, 9.17 \mathrm{~g}\right.$, $27.0 \mathrm{mmol})$, hexanes $(360 \mathrm{~mL}), \mathrm{H}_{2} \mathrm{O}(50.0 \mathrm{~mL})$ and $\mathrm{S}-(+)$-epichlorohydrin $(100 \mathrm{~g}, 1.08 \mathrm{~mol})$ was added. The reaction was allowed to proceed for $8 \mathrm{hr}$ before $500 \mathrm{~mL}$ of brine was added and the crude product obtained by way of extraction into 3 x $500 \mathrm{~mL}$ DCM. The organic layers were combined, dried over $\mathrm{Na}_{2} \mathrm{SO}_{4}$, and concentrated under vacuum. Column chromatography (75\% hexanes/DCM to DCM) of the crude material was used to purify the product. Residual S-(+)-epichlorohydrin was removed under reduced pressure overnight to yield the product (47.3 g, $422 \mathrm{mmol}, 78 \%$ ) as a faint yellow oil. HRMS-ESI for R-(-)-GPE; Calcd for $\mathrm{C}_{6} \mathrm{H}_{8} \mathrm{O}_{2}: \mathrm{m} / \mathrm{z}=130.0868[\mathrm{M}+\mathrm{NH}]^{+}$; Found: $130.0862\left[\mathrm{M}+\mathrm{NH}_{4}\right]^{+} .{ }^{1} \mathrm{H} \mathrm{NMR}\left(500 \mathrm{MHz}, \mathrm{CDCl}_{3}\right): \delta(\mathrm{ppm}) 4.19(\mathrm{t}, J=2.4 \mathrm{~Hz}, 2 \mathrm{H}), 3.80(\mathrm{dd}, J=11.4,2.9$ $\mathrm{Hz}, 1 \mathrm{H}), 3.46(\mathrm{dd}, J=11.3,5.9 \mathrm{~Hz}, 1 \mathrm{H}), 3.19-3.10(\mathrm{~m}, 1 \mathrm{H}), 2.78(\mathrm{dd}, J=5.2,4.1 \mathrm{~Hz}, 1 \mathrm{H}), 2.61(\mathrm{dd}, J=5.1,2.6$ $\mathrm{Hz}, 1 \mathrm{H}), 2.43(\mathrm{t}, J=2.3 \mathrm{~Hz}, 1 \mathrm{H}) .{ }^{13} \mathrm{C} \mathrm{NMR}\left(125 \mathrm{MHz}, \mathrm{CDCl}_{3}\right): \delta(\mathrm{ppm}) 79.2,74.8,70.3,58.4,50.4,44.2$. 


\section{2) Monomer 1-alkyne}

a) $R 1$

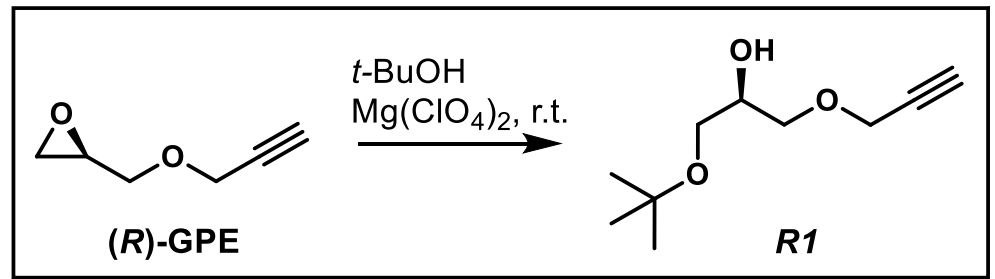

$\boldsymbol{R} 1$ : Under an $\mathrm{N}_{2}$ atmosphere, dry, liquid $t$-BuOH (119.0 g, $\left.1.60 \mathrm{~mol}\right)$ was added to $(\boldsymbol{R})-\mathbf{G P E}(30.0 \mathrm{~g}, 268 \mathrm{mmol})$ in an oven-dried and sealed $500 \mathrm{~mL}$ round-bottom flask in a room temperature water bath. $\mathrm{Next}, \mathrm{Mg}\left(\mathrm{ClO}_{4}\right)_{2}(15.0 \mathrm{~g}$, $67.1 \mathrm{mmol}$ ) was added portion-wise into the stirring reaction mixture. This mixture was allowed to react for $24 \mathrm{~h}$. After completion, $500 \mathrm{~mL}$ of water was added to the solution followed by extraction with DCM (3 x $500 \mathrm{~mL})$. The organic layers were combined, dried with $\mathrm{Na}_{2} \mathrm{SO}_{4}$, and concentrated under vacuum. Column chromatography (50\% hexanes/DCM to $100 \%$ DCM) yielded the product (48.3 g, 259 mmol, 97\% yield). HRMS-ESI for R1; Calcd for $\mathrm{C}_{10} \mathrm{H}_{18} \mathrm{O}_{3}: \mathrm{m} / \mathrm{z}=204.1594\left[\mathrm{M}+\mathrm{NH}_{4}\right]^{+} ;$Found: $204.1601\left[\mathrm{M}+\mathrm{NH}_{4}\right]^{+} .{ }^{1} \mathrm{H} \mathrm{NMR}(500 \mathrm{MHz}, \mathrm{CDCl}): \delta(\mathrm{ppm}) 4.20(\mathrm{~d}$, $J=2.3 \mathrm{~Hz}, 2 \mathrm{H}), 3.91(\mathrm{ddd}, J=10.7,6.2,4.5 \mathrm{~Hz}, 1 \mathrm{H}), 3.62(\mathrm{dd}, J=9.7,4.5 \mathrm{~Hz}, 1 \mathrm{H}), 3.56(\mathrm{dd}, J=9.7,6.0 \mathrm{~Hz}, 1 \mathrm{H})$, $3.44(\mathrm{dd}, J=9.1,4.5 \mathrm{~Hz}, 1 \mathrm{H}), 3.38(\mathrm{dd}, J=9.0,6.5 \mathrm{~Hz}, 1 \mathrm{H}), 2.58-2.44(\mathrm{br}, 1 \mathrm{H}), 2.44(\mathrm{t}, J=2.4 \mathrm{~Hz}, 1 \mathrm{H}), 1.19(\mathrm{~s}$, 9H). ${ }^{13} \mathrm{C} \mathrm{NMR}\left(125 \mathrm{MHz}, \mathrm{CDCl}_{3}\right): \delta(\mathrm{ppm}) 77.2,74.6,73.0,71.1,69.5,62.7,58.3,53.4,27.3$.

b) $R 2$

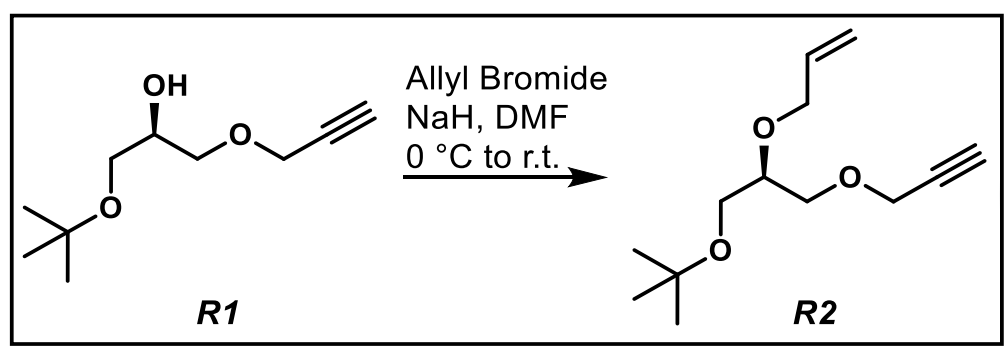

$\boldsymbol{R} 2$ : Under an $\mathrm{N}_{2}$ atmosphere, dry DMF (190 mL) and allyl bromide (34.2 g, $\left.282 \mathrm{mmol}, 23.2 \mathrm{~mL}\right)$ were added to $\boldsymbol{R} \boldsymbol{I}$ $(35.0 \mathrm{~g}, 188 \mathrm{mmol})$ in an oven-dried and sealed $500 \mathrm{~mL}$ round-bottom flask. The reaction mixture was cooled to 0 ${ }^{\circ} \mathrm{C}$ and $60 \% \mathrm{NaH}$ in mineral oil $(8.28 \mathrm{~g}, 207 \mathrm{mmol})$ was added portion-wise into the stirring reaction mixture. The mixture was allowed to gradually warm to room temperature and left to react overnight. After completion, DMF was removed under reduced pressure. $300 \mathrm{~mL}$ of water was added to the solution which was extracted with DCM (3 $\mathrm{x}$ 
$500 \mathrm{~mL}$ ). The organic layers were combined, dried with $\mathrm{Na}_{2} \mathrm{SO}_{4}$, and concentrated under vacuum. Column chromatography (80\% Hexanes/DCM to 50\% Hexanes/DCM) yielded the product (40.5 g, $179 \mathrm{mmol}$, 95\% yield). HRMS-ESI for $R 2$; Calcd for $\mathrm{C}_{13} \mathrm{H}_{22} \mathrm{O}_{3}: \mathrm{m} / \mathrm{z}=244.1907\left[\mathrm{M}+\mathrm{NH}_{4}\right]^{+}$; Found: $244.1910\left[\mathrm{M}+\mathrm{NH}_{4}\right]^{+}$. ${ }^{1} \mathrm{H} \mathrm{NMR}(500$ $\mathrm{MHz}, \mathrm{CDCl}$ ): $\delta(\mathrm{ppm}) 5.92(\mathrm{ddt}, J=16.1,10.4,5.7 \mathrm{~Hz}, 1 \mathrm{H}), 5.28(\mathrm{~d}, J=17.2 \mathrm{~Hz}, 1 \mathrm{H}), 5.15(\mathrm{~d}, J=10.4 \mathrm{~Hz}, 1 \mathrm{H})$, $4.20-4.18(\mathrm{~d}, J=2.5 \mathrm{~Hz}, 2 \mathrm{H}), 4.16-4.14(\mathrm{~m}, 2 \mathrm{H}), 3.69-3.66(\mathrm{~m}, 1 \mathrm{H}), 3.63-3.57(\mathrm{~m}, 2 \mathrm{H}), 3.44(\mathrm{~d}, J=5.5 \mathrm{~Hz}, 2 \mathrm{H})$, $2.42(\mathrm{t}, J=2.3 \mathrm{~Hz}, 1 \mathrm{H}), 1.18(\mathrm{~s}, 9 \mathrm{H}) .{ }^{13} \mathrm{C} \mathrm{NMR}\left(125 \mathrm{MHz}, \mathrm{CDCl}_{3}\right): \delta(\mathrm{ppm}) 135.1,116.9,94.8,77.3,74.6,73.3,71.3$, $69.9,61.5,58.5,25.3$.

c) $R 3$

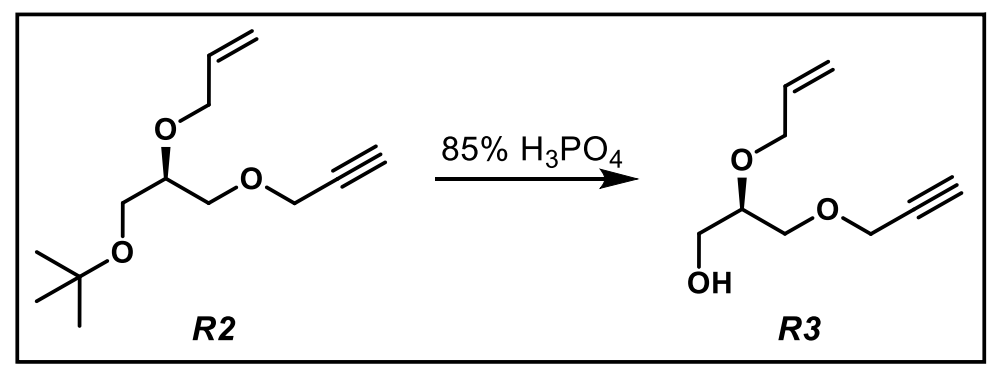

R3: Under an $\mathrm{N}_{2}$ atmosphere, $85 \% \mathrm{H}_{3} \mathrm{PO}_{4}(175 \mathrm{~g}, 1.78 \mathrm{~mol})$ was poured onto $\boldsymbol{R 2}(40.0 \mathrm{~g}, 178 \mathrm{mmol})$ in a $500 \mathrm{~mL}$ round-bottom flask. The reaction mixture was stirred and left to react at room temperature over $4 \mathrm{~h}$. After completion, $500 \mathrm{~mL}$ of water was added to the solution followed by extraction with DCM $(3 \times 500 \mathrm{~mL})$. The organic layers were combined, dried with $\mathrm{Na}_{2} \mathrm{SO}_{4}$, and concentrated under vacuum. Column chromatography (50\% Hexanes/DCM to $2 \% \mathrm{MeOH} / \mathrm{DCM}$ ) yielded the product (25.6 g, 150. mmol, 84\% yield). HRMS-ESI for R3; Calcd for $\mathrm{C}_{9} \mathrm{H}_{14} \mathrm{O}_{3}: \mathrm{m} / \mathrm{z}=188.1281\left[\mathrm{M}+\mathrm{NH}_{4}\right]^{+}$; Found: $188.1286\left[\mathrm{M}+\mathrm{NH}_{4}\right]^{+} .{ }^{1} \mathrm{H}$ NMR $(500 \mathrm{MHz}, \mathrm{CDCl} 3): \delta(\mathrm{ppm}) 5.97$ - $5.88(\mathrm{ddt}, 16.0,10.4,5.6 \mathrm{~Hz}, 1 \mathrm{H}), 5.29(\mathrm{dd}, J=17.2,1.5 \mathrm{~Hz}, 1 \mathrm{H}), 5.19(\mathrm{dd}, J=10.4,1.2 \mathrm{~Hz}, 1 \mathrm{H}), 4.21-4.16$ (overlap, 3H), 4.12-4.08 (m, 1H), 3.79-3.70 (m, 1H), 3.67-3.62 (overlap, 4H), $2.45(\mathrm{t}, J=2.4 \mathrm{~Hz}, 1 \mathrm{H}), 1.99$ (br, 1H). ${ }^{13} \mathrm{C}$ NMR $\left(125 \mathrm{MHz}, \mathrm{CDCl}_{3}\right): \delta(\mathrm{ppm}) 134.7,117.6,94.9,77.8,75.0,71.2,69.5,62.5,58.7$. 
d) $R 4$

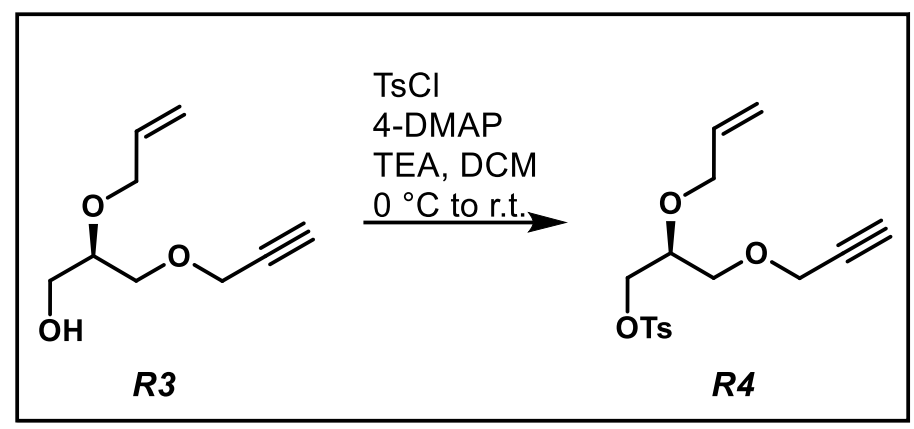

R4: Under an $\mathrm{N}_{2}$ atmosphere, dry DCM $(500 \mathrm{~mL})$, triethylamine $(16.7 \mathrm{~g}, 165.4 \mathrm{mmol}, 22.88 \mathrm{~mL})$, and 4dimethylaminopyridine (4-DMAP) (9.19 g, $75.2 \mathrm{mmol}$ ) were added to $\boldsymbol{R} 3$ (25.5 g, 150. mmol) in an oven-dried and sealed $1000 \mathrm{~mL}$ round-bottom flask. The reaction mixture was cooled to $0{ }^{\circ} \mathrm{C}$ and 4 -toluenesulfonyl chloride (31.5 $\mathrm{g}, 165 \mathrm{mmol}$ ) was added portion-wise into the stirring reaction mixture. The mixture was allowed to gradually warm up to room temperature and left to react overnight. After completion, the organic solution was extracted with water $(3 \times 300 \mathrm{~mL})$ and brine $(1 \times 300 \mathrm{~mL})$. The organic layer was dried with $\mathrm{Na}_{2} \mathrm{SO}_{4}$ and concentrated under vacuum. Column chromatography (50\% Hexanes/DCM to 100\% DCM) yielded the product (38.2 g, 118 mmol, 78\% yield). HRMS-ESI for R4; Calcd for $\mathrm{C}_{16} \mathrm{H}_{20} \mathrm{O}_{5} \mathrm{~S}: \mathrm{m} / \mathrm{z}=342.1370\left[\mathrm{M}+\mathrm{NH}_{4}\right]^{+}$; Found: $342.1372\left[\mathrm{M}+\mathrm{NH}_{4}\right]^{+} .{ }^{1} \mathrm{H} \mathrm{NMR}(500$ $\left.\mathrm{MHz}, \mathrm{CDCl}_{3}\right): \delta(\mathrm{ppm}) 7.80(\mathrm{~d}, J=8.3 \mathrm{~Hz}, 2 \mathrm{H}), 7.34(\mathrm{~d}, J=8.5 \mathrm{~Hz}, 2 \mathrm{H}), 5.86-5.78(\mathrm{ddt}, 17.2 \mathrm{~Hz}, 10.4 \mathrm{~Hz}, 4.2 \mathrm{~Hz}, 1 \mathrm{H})$, $5.23(\mathrm{dd}, J=17.2,1.6 \mathrm{~Hz}, 1 \mathrm{H}), 5.16(\mathrm{dd}, J=10.4 \mathrm{~Hz}, 1.2 \mathrm{~Hz}, 1 \mathrm{H}), 4.17-4.02$ (overlap, $6 \mathrm{H}), 3.73(\mathrm{p}, J=4.8 \mathrm{~Hz}, 1 \mathrm{H})$, $3.57(\mathrm{~d}, J=5.1 \mathrm{~Hz}, 1 \mathrm{H}), 2.45(\mathrm{~s}, 3 \mathrm{H}), 2.43(\mathrm{t}, J=2.4 \mathrm{~Hz}, 1 \mathrm{H}) .{ }^{13} \mathrm{C} \mathrm{NMR}\left(125 \mathrm{MHz}, \mathrm{CDCl}_{3}\right): \delta(\mathrm{ppm}) 144.8,134.2$, 132.6, 129.8, 127.9, 117.4, 94.7, 79.1, 75.0, 71.2, 69.2, 68.1, 58.5, 21.5.

e) 1-alkyne

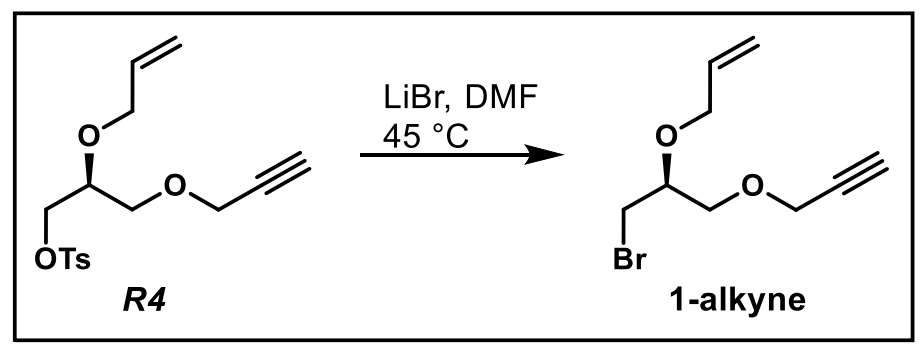

1-alkyne: DMF (250 mL) and $\mathrm{LiBr}(44.1 \mathrm{~g}, 507.5 \mathrm{mmol})$ were added to $\boldsymbol{R} 4(38.0 \mathrm{~g}, 118 \mathrm{mmol})$ in a $500 \mathrm{~mL}$ roundbottom flask. The reaction mixture was left to stir until the $\mathrm{LiBr}$ was completely dissolved, after which the mixture 
was placed into a $45^{\circ} \mathrm{C}$ oil bath and left to react overnight. DMF was then removed under reduced pressure. $300 \mathrm{~mL}$ of water was added to the solution followed by extraction with DCM (3 x $500 \mathrm{~mL})$. The organic layers were combined, dried with $\mathrm{Na}_{2} \mathrm{SO}_{4}$, and concentrated under vacuum. Column chromatography (50\% hexanes/DCM to $100 \%$ DCM) yielded the product $\left(24.1 \mathrm{~g}, 103\right.$ mmol, $88 \%$ yield). HRMS-ESI for 1-alkyne; $\mathrm{Calcd}_{\text {for }} \mathrm{C}_{9} \mathrm{H}_{13} \mathrm{BrO}_{2}$ : $\mathrm{m} / \mathrm{z}=250.0437\left[\mathrm{M}+\mathrm{NH}_{4}\right]^{+} ;$Found: $250.0443\left[\mathrm{M}+\mathrm{NH}_{4}\right]^{+} .{ }^{1} \mathrm{H}$ NMR $\left(500 \mathrm{MHz}, \mathrm{CDCl}_{3}\right): \delta(\mathrm{ppm}) 5.97-5.89(\mathrm{ddt}, J=$ $17.2,10.4,5.8 \mathrm{~Hz}, 1 \mathrm{H}), 5.31(\mathrm{dd}, J=17.2,1.6 \mathrm{~Hz}, 1 \mathrm{H}), 5.21(\mathrm{dd}, J=10.4,1.2 \mathrm{~Hz}, 1 \mathrm{H}), 4.20(\mathrm{~d}, J=2.4 \mathrm{~Hz}, 2 \mathrm{H})$, 4.15-4.12 (m, 2H), 3.75-3.66 (overlap, 3H), $3.54(\mathrm{dd}, J=10.6,5.3 \mathrm{~Hz}, 1 \mathrm{H}), 3.47(\mathrm{dd}, J=10.6,4.7 \mathrm{~Hz}, 1 \mathrm{H}), 2.45(\mathrm{t}$, $J=2.4 \mathrm{~Hz}, 1 \mathrm{H}) .{ }^{13} \mathrm{C} \mathrm{NMR}\left(125 \mathrm{MHz}, \mathrm{CDCl}_{3}\right): \delta(\mathrm{ppm}) 134.3,117.4,79.2,76.6,74.8,71.0,69.5,58.5,32.0$.

\section{2) Monomer 1-alkyne}

a) $R 5$

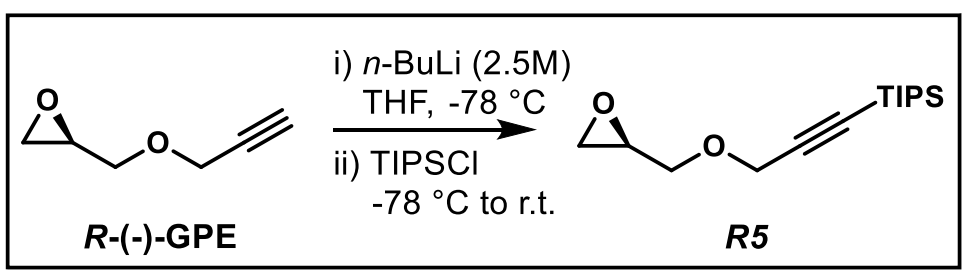

R5: Under an $\mathrm{N}_{2}$ atmosphere, $\boldsymbol{R}$-(-)-GPE (16.0 g, $143 \mathrm{mmol}$ ) was added to dry THF (300 mL) in an oven-dried and sealed $500 \mathrm{~mL}$ two-neck round-bottom flask attached to a $150 \mathrm{~mL}$ addition funnel. Next, the reaction vessel was cooled to $-78^{\circ} \mathrm{C}$ using a dry ice/pentanes bath, followed by the dropwise addition of $n$-butyllithium ( $n$-BuLi) (2.5 M in hexanes, $63.0 \mathrm{~mL}, 157 \mathrm{mmol})$. Once all of the $n$-BuLi was added, the addition funnel was washed with $\sim 10 \mathrm{~mL}$ of dry THF and the reaction mixture was allowed to stir for $30 \mathrm{~min}$. Then, triisopropylsilyl chloride (TIPSCl) (30.3 g, $157.1 \mathrm{mmol}, 33.6 \mathrm{~mL}$ ) was added to the addition funnel, followed by the dropwise addition of the TIPSCl to the reaction mixture $\left(\right.$ still at $-78^{\circ} \mathrm{C}$ ) over the course of 15 min. After warming to room temperature, the reaction proceeded for 3-4 h before being quenched upon addition of a cold brine solution ( $500 \mathrm{~mL})$. The crude product was obtained by extraction into DCM $(3 \times 500 \mathrm{~mL})$, followed by combining the organic layers, drying with $\mathrm{Na}_{2} \mathrm{SO}_{4}$, and concentrating under vacuum. Column chromatography (4\% EtOAc/hexanes) of the crude material yielded the product (27.4 g, $102 \mathrm{mmol}, 71 \%$ yield) as a clear oil. HRMS-ESI for R5; Calcd for $\mathrm{C}_{6} \mathrm{H}_{8} \mathrm{O}_{2}: \mathrm{m} / \mathrm{z}=130.0868[\mathrm{M}+$ $\left.\mathrm{NH}_{4}\right]^{+}$; Found: $130.0862\left[\mathrm{M}+\mathrm{NH}_{4}\right]^{+} .{ }^{1} \mathrm{H} \mathrm{NMR}\left(500 \mathrm{MHz}, \mathrm{CDCl}_{3}\right): \delta(\mathrm{ppm}) 4.26(\mathrm{~d}, J=9.6 \mathrm{~Hz}, 2 \mathrm{H}), 3.82(\mathrm{dd}, J=$ $11.2,3.3 \mathrm{~Hz}, 1 \mathrm{H}), 3.53(\mathrm{dd}, J=11.2,5.7 \mathrm{~Hz}, 1 \mathrm{H}), 3.18(\mathrm{dq}, J=6.0,3.1 \mathrm{~Hz}, 1 \mathrm{H}), 2.81(\mathrm{t}, J=4.6 \mathrm{~Hz}, 1 \mathrm{H}), 2.64(\mathrm{dd}, J$ 
= 5.0, $2.7 \mathrm{~Hz}, 1 \mathrm{H}), 1.07(\mathrm{~s}, 21 \mathrm{H}) .{ }^{13} \mathrm{C} \mathrm{NMR}\left(125 \mathrm{MHz}, \mathrm{CDCl}_{3}\right): \delta(\mathrm{ppm}) 101.6,90.1,70.2,59.2,50.6,44.5,18.5$, 11.0.

b) $R 6$

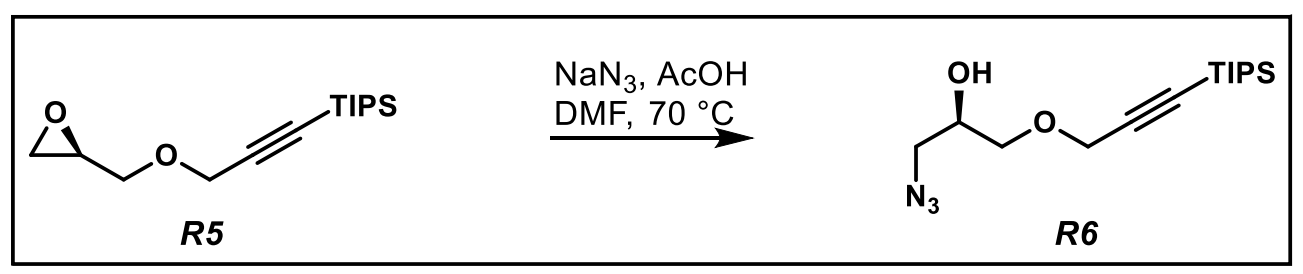

R6: DMF (700 mL) and acetic acid $(9.20 \mathrm{~g}, 153 \mathrm{mmol}, 8.76 \mathrm{~mL})$ were added to $\boldsymbol{R} 5(27.3 \mathrm{~g}, 102 \mathrm{mmol})$ in a 1000 $\mathrm{mL}$ round-bottom flask. $\mathrm{NaN}_{3}(19.9 \mathrm{~g}, 306 \mathrm{mmol})$ was then added and the reaction mixture was heated to $70{ }^{\circ} \mathrm{C}$ and allowed to stir for $24 \mathrm{~h}$. Over the course of the reaction a white gel-like precipitate formed. DMF was then removed under reduced pressure. $300 \mathrm{~mL}$ of water was added to the solution followed by extraction with DCM (3 x $300 \mathrm{~mL})$. The organic layers were combined, dried with $\mathrm{Na}_{2} \mathrm{SO}_{4}$, and concentrated under vacuum. Column chromatography (10\% EtOAc/hexanes) yielded the product (26.3 g, $84.4 \mathrm{mmol}, 82.8 \%$ yield). Safety warning: Though we have not experienced any issues with this reaction procedure, it should be noted that sodium azide in the presence of acid can produce hydrazoic acid, a highly toxic and flammable gas. All of these procedures are performed in a well-ventilated fume hood in order to minimize danger. The reaction mixture can also be neutralized by addition of $50 \mathrm{~mL}$ of a saturated $\mathrm{NaHCO}_{3}$ solution before removal of DMF under reduced pressure. HRMS-ESI for R6; Calcd for $\mathrm{C}_{15} \mathrm{H}_{29} \mathrm{~N}_{3} \mathrm{O}_{2} \mathrm{Si}: \mathrm{m} / \mathrm{z}=329.2367\left[\mathrm{M}+\mathrm{NH}_{4}\right]^{+}$; Found: $329.2367\left[\mathrm{M}+\mathrm{NH}_{4}\right]^{+} .{ }^{1} \mathrm{H}$ NMR $\left(500 \mathrm{MHz}, \mathrm{CDCl}_{3}\right): \delta(\mathrm{ppm})$ $4.24(\mathrm{~s}, 2 \mathrm{H}), 3.98(\mathrm{p}, J=5.9 \mathrm{~Hz}, 1 \mathrm{H}), 3.64(\mathrm{dd}, J=9.6,4.1 \mathrm{~Hz}, 1 \mathrm{H}), 3.58(\mathrm{dd}, J=9.6,6.1 \mathrm{~Hz}, 1 \mathrm{H}), 3.39(\mathrm{dd}, J=$ 5.2, $0.7 \mathrm{~Hz}, 2 \mathrm{H}), 2.34$ (br, 1H), 1.07 (s, 21H). ${ }^{13} \mathrm{C} \mathrm{NMR}\left(125 \mathrm{MHz}, \mathrm{CDCl}_{3}\right): \delta(\mathrm{ppm}) 102.6,94.8,88.3,77.2,70.8$, $69.5,59.3,18.5,11.1$. 
c) $1-N_{3}$

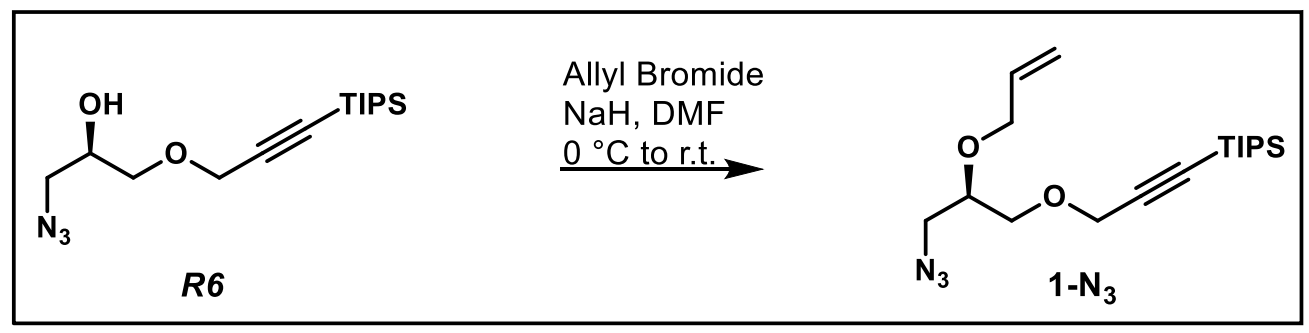

2S: Under an $\mathrm{N}_{2}$ atmosphere, dry DMF $(250 \mathrm{~mL})$ and allyl bromide $(15.2 \mathrm{~g}, 126 \mathrm{mmol}, 10.3 \mathrm{~mL})$ were added to $\boldsymbol{R} \boldsymbol{6}$ $(26.0 \mathrm{~g}, 83.7 \mathrm{mmol})$ in an oven-dried and sealed $500 \mathrm{~mL}$ round-bottom flask. The reaction mixture was cooled to 0 ${ }^{\circ} \mathrm{C}$ and $60 \% \mathrm{NaH}$ in mineral oil $(3.68 \mathrm{~g}, 92.1 \mathrm{mmol})$ was added portion-wise into the stirring reaction mixture. The mixture was allowed to gradually warm up to room temperature and left to react overnight. After completion, DMF was removed under reduced pressure. $250 \mathrm{~mL}$ of water was added to the solution which was extracted with DCM (3 x $250 \mathrm{~mL}$ ). The organic layers were combined, dried with $\mathrm{Na}_{2} \mathrm{SO}_{4}$, and concentrated under vacuum. Column chromatography (5\% EtOAc/hexanes) yielded the product (25.8 g, $73.4 \mathrm{mmol}, 88 \%$ yield). HRMS-ESI for 1-N $\mathbf{N}_{\mathbf{3}}$; Calcd for $\mathrm{C}_{18} \mathrm{H}_{33} \mathrm{~N}_{3} \mathrm{O}_{2} \mathrm{Si}: \mathrm{m} / \mathrm{z}=352.2415[\mathrm{M}+\mathrm{H}]^{+}$; Found: $352.2426[\mathrm{M}+\mathrm{H}]^{+}$. ${ }^{1} \mathrm{H}$ NMR $\left(500 \mathrm{MHz}, \mathrm{CDCl}_{3}\right)$ : $\delta(\mathrm{ppm}) 5.93(\mathrm{ddt}, J=16.2,10.8,5.7 \mathrm{~Hz}, 1 \mathrm{H}), 5.30(\mathrm{dd}, J=17.2,1.5 \mathrm{~Hz}, 1 \mathrm{H}), 5.23-5.17(\mathrm{dd}, J=10.4,1.2 \mathrm{~Hz}, 1 \mathrm{H})$, $4.21(\mathrm{~s}, 3 \mathrm{H}), 4.17(\mathrm{dd}, J=12.7,5.7 \mathrm{~Hz}, 2 \mathrm{H}), 4.11(\mathrm{dd}, J=12.7,5.7 \mathrm{~Hz}, 2 \mathrm{H}), 3.69(\mathrm{~m}, 1 \mathrm{H}), 3.64(\mathrm{dd}, J=5.0,2.5 \mathrm{~Hz}$, 2H), $3.38(\mathrm{dd}, J=4.8 \mathrm{~Hz}, 0.7 \mathrm{~Hz}, 2 \mathrm{H}), 1.07(\mathrm{~s}, 21 \mathrm{H}) .{ }^{13} \mathrm{C} \mathrm{NMR}\left(125 \mathrm{MHz}, \mathrm{CDCl}_{3}\right): \delta(\mathrm{ppm}) 134.5,117.6,94.9,75.5$, 69.6, 67.0, 59.6, 52.6, 47.7, 18.7, 11.2.

\section{4) Allyl-IEG}

a) Dimer (2)

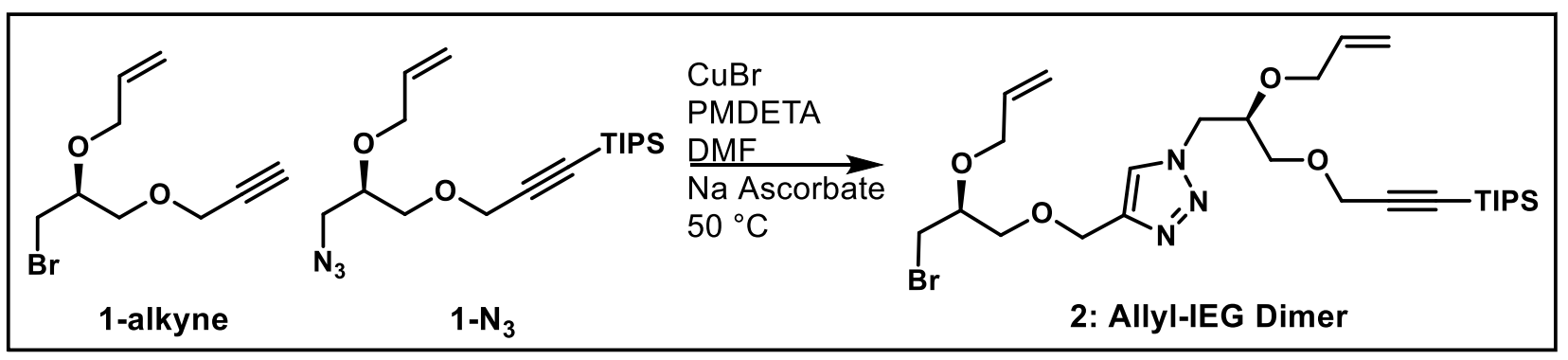

2: Under an $\mathrm{N}_{2}$ atmosphere, dry DMF (250 mL), $N, N, N^{\prime}, N^{\prime \prime}, N^{\prime \prime}$-pentamethyldiethylenetriamine (PMDETA) (1.26 g, $7.28 \mathrm{mmol}, 1.52 \mathrm{~mL})$, and $\mathrm{Na}$ ascorbate $(1.44 \mathrm{~g}, 7.28 \mathrm{mmol})$ were added to a mixture of 1-alkyne $(17.0 \mathrm{~g}, 72.9$ 
$\mathrm{mmol})$ and $\mathbf{1}-\mathbf{N}_{3}(25.6 \mathrm{~g}, 72.8 \mathrm{mmol})$ in an oven-dried and sealed $500 \mathrm{~mL}$ round-bottom flask. CuBr $(522 \mathrm{mg}, 3.64$ mmol) was then added and the reaction mixture was warmed to $50{ }^{\circ} \mathrm{C}$ and left overnight. After completion, DMF was removed under reduced pressure. $10 \mathrm{~mL}$ of DCM was added to the resulting viscous mixture, which was then loaded carefully onto a column. Column chromatography (25\% hexanes/DCM to $2 \% \mathrm{MeOH} / \mathrm{DCM}$ ) yielded the product (37.9 g, $64.8 \mathrm{mmol}, 89 \%$ yield) as a faint yellow oil. HRMS-ESI for 2; Calcd for $\mathrm{C}_{27} \mathrm{H}_{46} \mathrm{BrN}_{3} \mathrm{O}_{4} \mathrm{Si}$ : $\mathrm{m} / \mathrm{z}=$ $584.2514[\mathrm{M}+\mathrm{H}]^{+}$; Found: $584.2490[\mathrm{M}+\mathrm{H}]^{+} .{ }^{1} \mathrm{H}$ NMR $\left(500 \mathrm{MHz}, \mathrm{CDCl}_{3}\right): \delta(\mathrm{ppm}) 7.65(\mathrm{~s}, 1 \mathrm{H}), 5.89(\mathrm{ddt}, J=$ $16.3,10.4,5.7 \mathrm{~Hz}, 1 \mathrm{H}), 5.71(\mathrm{ddt}, J=16.5,10.3,5.8 \mathrm{~Hz}, 1 \mathrm{H}), 5.28(\mathrm{dd}, J=17.3,1.7 \mathrm{~Hz}, 1 \mathrm{H}), 5.19$ - 5.10 (overlap, 3H), $4.67(\mathrm{~d}, J=2.3 \mathrm{~Hz}, 2 \mathrm{H}), 4.60(\mathrm{dd}, J=14.2,3.4 \mathrm{~Hz}, 1 \mathrm{H}), 4.41(\mathrm{dd}, J=14.2,8.0 \mathrm{~Hz}, 1 \mathrm{H}), 4.24(\mathrm{~d}, J=2.4 \mathrm{~Hz}$, 2H), $4.10(\mathrm{dd}, J=5.8,4.3 \mathrm{~Hz}, 2 \mathrm{H}), 4.03(\mathrm{dd}, J=12.7,5.7 \mathrm{~Hz}, 2 \mathrm{H}), 3.92-3.85$ (overlap, 2H), $3.72-3.67(\mathrm{~m}, 1 \mathrm{H})$, $3.67-3.60$ (overlap, 3H), $3.51(\mathrm{dd}, J=10.6,5.2 \mathrm{~Hz}, 1 \mathrm{H}), 3.43(\mathrm{dd}, J=10.6,4.7 \mathrm{~Hz}, 1 \mathrm{H}), 1.06(\mathrm{~s}, 21 \mathrm{H}) .{ }^{13} \mathrm{C}$ NMR $\left(125 \mathrm{MHz}, \mathrm{CDCl}_{3}\right): \delta(\mathrm{ppm}) 144.5,134.5,134.0,124.2,117.8,117.6,102.6,96.3,94.3,88.4,76.3,71.2,70.1,67.9$, $64.9,59.5,51.8,32.2,18.6,11.1$.

\section{b) Tetramer (4)}

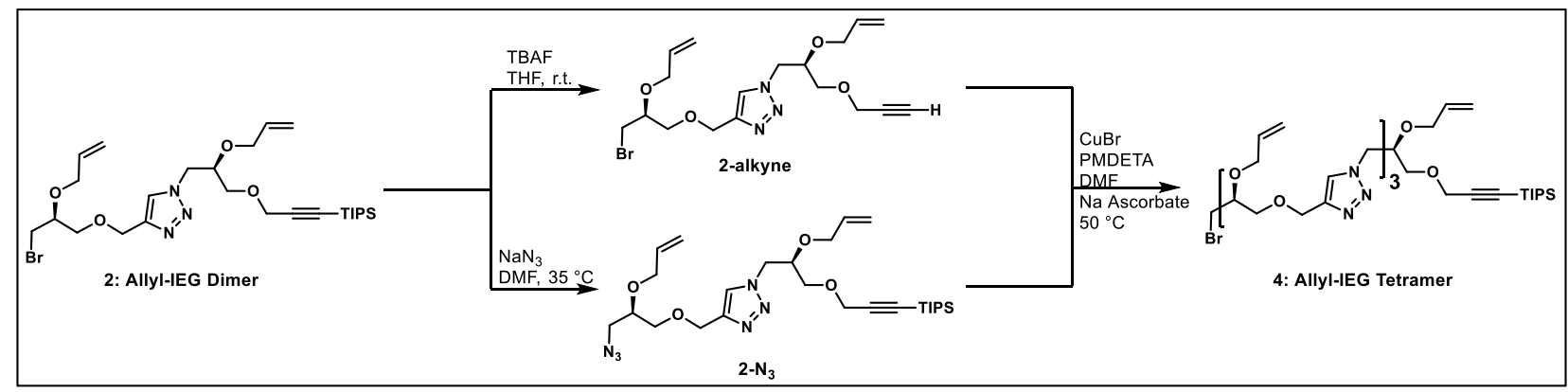

4: The 2-alkyne precursor to 4 was prepared by dissolving $2(13.11 \mathrm{~g}, 22.4 \mathrm{mmol})$ in THF (200 $\mathrm{mL})$, followed by the slow addition of tetrabutylammonium fluoride (TBAF) (1M in THF, 1.05 equiv, $23.55 \mathrm{~mL}$ ). After the reaction had gone to completion, THF was removed under reduced pressure. Next, the crude product mixture was purified by column chromatography ( $2 \% \mathrm{MeOH} / \mathrm{DCM})$ to yield 2-alkyne $(9.40 \mathrm{~g}, 21.9 \mathrm{mmol}, 97.9 \%$ yield) as a faint yellow oil. The $\mathbf{2}-\mathbf{N}_{3}$ precursor to 4 was prepared by dissolving $2(14.4 \mathrm{~g}, 24.6 \mathrm{mmol})$ in $300 \mathrm{~mL}$ DMF, followed by the addition of $\mathrm{NaN}_{3}(8.00 \mathrm{~g}, 123 \mathrm{mmol})$. The reaction mixture was heated to $35^{\circ} \mathrm{C}$ and allowed to stir for $12 \mathrm{~h}$ before the DMF was removed via rotary evaporator at $35{ }^{\circ} \mathrm{C}$. Heating past $35{ }^{\circ} \mathrm{C}$ was avoided as it leads to degradation of the product. Then, $500 \mathrm{~mL}$ of EtOAc was added to the residue and extracted with water $(2 \times 300 \mathrm{~mL})$ and brine $(1 \times 300$ 
$\mathrm{mL}$ ). The organic layer was dried with $\mathrm{Na}_{2} \mathrm{SO}_{4}$ and concentrated under vacuum. The compound $\mathbf{2}-\mathbf{N}_{\mathbf{3}}$ was obtained (12.6 g, $23.1 \mathrm{mmol}, 94 \%)$ as a faint yellow oil.

Under an $\mathrm{N}_{2}$ atmosphere, dry DMF (200 mL), PMDETA (361 mg, $2.09 \mathrm{mmol}, 0.435 \mathrm{~mL}$ ), and Na ascorbate (826 $\mathrm{mg}, 4.170 \mathrm{mmol})$ were added to a mixture of $\mathbf{2}$-alkyne $(9.40 \mathrm{~g}, 21.9 \mathrm{mmol})$ and $\mathbf{2}-\mathbf{N}_{\mathbf{3}}(12.6 \mathrm{~g}, 23.1 \mathrm{mmol})$ in an oven-dried and sealed $500 \mathrm{~mL}$ round-bottom flask. $\mathrm{CuBr}(150 . \mathrm{mg}, 1.04 \mathrm{mmol})$ was then added and the reaction mixture was warmed to $50{ }^{\circ} \mathrm{C}$ and left to react for $2 \mathrm{~h}$. After completion, DMF was removed under reduced pressure. $10 \mathrm{~mL}$ of DCM was added to the resulting viscous mixture which was then loaded carefully onto a column. Column chromatography (100\% DCM to 4\% MeOH/DCM) yielded the product (19.3 g, $19.8 \mathrm{mmol}, 88.4 \%$ yield from 2 ) as a yellow oil. ${ }^{1} \mathrm{H}$ NMR $\left(500 \mathrm{MHz}, \mathrm{CDCl}_{3}\right): \delta(\mathrm{ppm}) 7.67$ (s, 2H), $7.65(\mathrm{~s}, 1 \mathrm{H}), 5.89$ (ddt, $\left.J=17.3,10.3,5.7 \mathrm{~Hz}, 1 \mathrm{H}\right)$, 5.75-5.67 (overlap, 3H), 5.28 (dq, $J=17.2,1.6 \mathrm{~Hz}, 1 \mathrm{H}$ ), 5.19-5.09 (overlap, 7H), 4.70-4.56 (overlap, 10H), 4.464.38 (overlap, 3H), 4.24 (d, $J=2.7 \mathrm{~Hz}, 2 \mathrm{H}$ ), 4.10 (tt, $J=4.3,1.4 \mathrm{~Hz}, 1 \mathrm{H}$ ), 4.03 (overlap, 3H), 3.98-3.86 (overlap, 6H), 3.69 (dd, $J=9.7,4.8 \mathrm{~Hz}, 1 \mathrm{H}), 3.66-3.61$ (overlap, 3H), 3.58-3.49 (overlap, 4H), 3.51 (dd, $J=10.7,5.2 \mathrm{~Hz}$, $1 \mathrm{H}), 3.44(\mathrm{dd}, J=10.6,4.7 \mathrm{~Hz}, 1 \mathrm{H}) 1.06(\mathrm{~s}, 21 \mathrm{H}) .{ }^{13} \mathrm{C} \mathrm{NMR}\left(125 \mathrm{MHz}, \mathrm{CDCl}_{3}\right): \delta(\mathrm{ppm}) 144.0,134.3,134.2,134.1$, 133.8, 133.7, 133.7, 133.7, 124.3, 117.6, 117.5, 117.4, 117.3, 117.3, 117.2, 101.3, 90.2, 76.6, 76.0, 75.9, 70.9, 69.8, $68.6,67.8,64.5,64.4,59.2,51.5,51.2,51.2,32.1,25.9,25.8,25.7,16.2,-4.9,-4.9 .$.

c) Octamer (8)

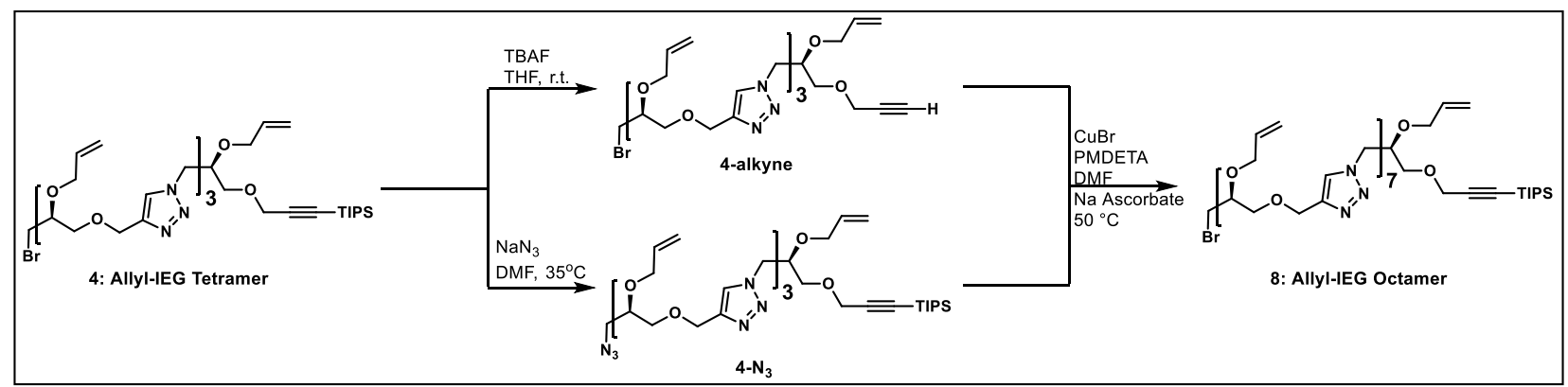

8: The 4-alkyne precursor to 8 was prepared by dissolving $4(7.5 \mathrm{~g}, 7.69 \mathrm{mmol})$ in THF ( $80 \mathrm{~mL})$, followed by the slow addition of TBAF (1M in THF, 1.05 equiv, $8.07 \mathrm{~mL}$ ). After the reaction had gone to completion, THF was removed under reduced pressure. Then, the crude product mixture was purified by column chromatography (4\% $\mathrm{MeOH} / \mathrm{DCM}$ ) to yield 4-alkyne (5.56 g, $6.79 \mathrm{mmol}, 88 \%$ yield) as a yellow oil. 
The 4-N $\mathbf{N}_{3}$ precursor to $\mathbf{8}$ was prepared by dissolving $4(7.5 \mathrm{~g}, 7.69 \mathrm{mmol})$ in $80 \mathrm{~mL} \mathrm{DMF}$, followed by the addition of $\mathrm{NaN}_{3}(3.00 \mathrm{~g}, 46.2 \mathrm{mmol})$. The reaction mixture was heated to $35^{\circ} \mathrm{C}$ and allowed to stir for $12 \mathrm{~h}$ before the DMF was removed via rotary evaporator. Heating past $35{ }^{\circ} \mathrm{C}$ was avoided as it leads to degradation of the product. Then, $200 \mathrm{~mL}$ of EtOAc was added to the residue and the solution was extracted with water $(2 \times 200 \mathrm{~mL})$ and brine $(1 \mathrm{x}$ $200 \mathrm{~mL}$ ). The organic layer was dried with $\mathrm{Na}_{2} \mathrm{SO}_{4}$ and concentrated under vacuum. The compound 4-N $\mathbf{N}_{\mathbf{3}}$ was obtained (7.06 g, $7.53 \mathrm{mmol}, 97.9 \%)$ as a yellow oil.

Under an $\mathrm{N}_{2}$ atmosphere, dry DMF (70 mL), PMDETA (117 mg, $\left.0.674 \mathrm{mmol}, 0.140 \mathrm{~mL}\right)$, and Na ascorbate (267 $\mathrm{mg}, 1.348 \mathrm{mmol})$ were added to a mixture of 4-alkyne $(5.56 \mathrm{~g}, 6.79 \mathrm{mmol})$ and $\mathbf{4}-\mathbf{N}_{\mathbf{3}}(7.06 \mathrm{~g}, 7.53 \mathrm{mmol})$ in an oven-dried and sealed $500 \mathrm{~mL}$ round-bottom flask. CuBr $(48.4 \mathrm{mg}, 0.337 \mathrm{mmol})$ was then added and the reaction mixture was warmed to $50{ }^{\circ} \mathrm{C}$ and left to react for $2 \mathrm{~h}$. After completion, DMF was removed under reduced pressure. $5 \mathrm{~mL}$ of DCM was added to the resulting viscous mixture, which was then loaded onto a column. Column chromatography (100\% DCM to 6\% MeOH/DCM) yielded the product $(9.27 \mathrm{~g}, 5.23 \mathrm{mmol}, 69 \%$ yield from 4$)$ as a yellow oil. ${ }^{1} \mathrm{H}$ NMR (500 MHz, $\left.\mathrm{CDCl}_{3}\right): \delta(\mathrm{ppm}) 7.68(\mathrm{~s}, 6 \mathrm{H}), 7.65(\mathrm{~s}, 1 \mathrm{H}), 5.91(\mathrm{ddt}, J=17.3,10.4,5.7 \mathrm{~Hz}, 1 \mathrm{H})$, 5.75-5.67 (overlap, 7H), 5.29 (dq, $J=17.3 \mathrm{~Hz}, 1.6 \mathrm{~Hz}, 1 \mathrm{H}), 5.18-5.10$ (overlap, 15H), 4.70-4.56 (overlap, 22H), 4.44-4.38 (overlap, 8H), 4.26 (d, $J=2.8 \mathrm{~Hz}, 2 \mathrm{H}), 4.11$ (ddt, $J=5.7,4.4,1.4 \mathrm{~Hz}, 1 \mathrm{H}), 4.08-3.99$ (overlap, 7H), 3.923.86 (overlap, $14 \mathrm{H}), 3.70(\mathrm{dd}, J=9.7,4.8 \mathrm{~Hz}, 1 \mathrm{H}), 3.68-3.62$ (overlap, $4 \mathrm{H}), 3.58-3.50$ (overlap, $12 \mathrm{H}), 3.45(\mathrm{dd}, J=$ 10.6, 4.8, 1H), $1.06(\mathrm{~s}, 21 \mathrm{H}) .{ }^{13} \mathrm{C} \mathrm{NMR}\left(125 \mathrm{MHz}, \mathrm{CDCl}_{3}\right): \delta(\mathrm{ppm}) 143.7,143.4,134.0,133.9,133.5,133.5,123.9$, $123.8,116.9,116.8,116.6,102.2,87.5,76.1,75.6,75.5,70.5,70.4,70.3,68.2,67.4,64.0,58.7,53.3,51.0,50.8$, $50.7,50.6,31.9,30.3,30.2,18.0,10.4$ 


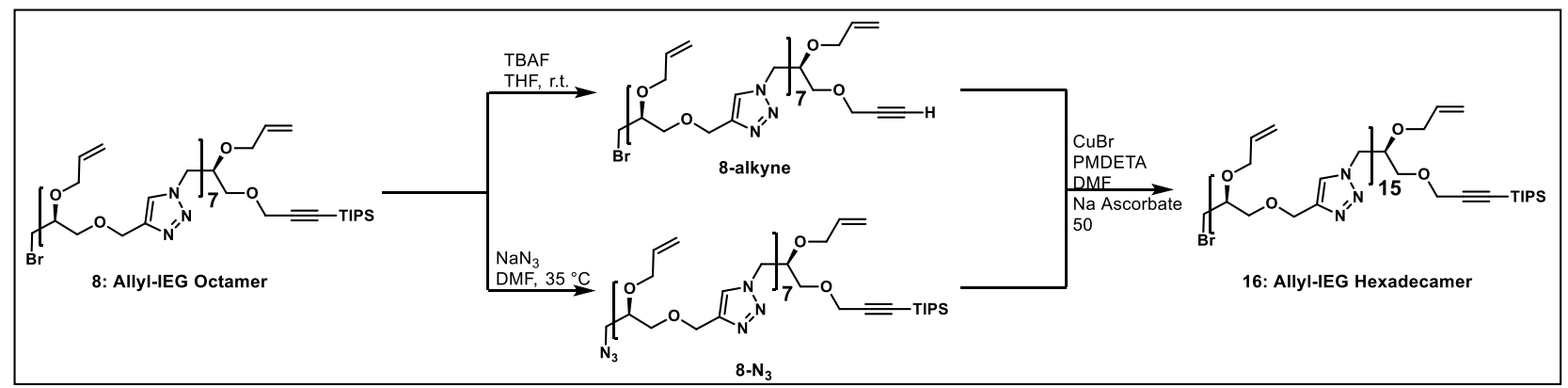

16: The 8-alkyne precursor to $\mathbf{1 6}$ was prepared by dissolving 8 (3.30 g, $1.88 \mathrm{mmol})$ in THF (38 $\mathrm{mL})$, followed by the slow addition of TBAF (1M in THF, 1.05 equiv, $1.97 \mathrm{~mL}$ ). After the reaction has gone to completion, THF was removed under reduced pressure. The crude product mixture was purified by column chromatography (6\% $\mathrm{MeOH} / \mathrm{DCM})$ to yield 8-alkyne (2.75 $\mathrm{g}, 1.72 \mathrm{mmol}, 91.4 \%$ yield) as a yellow oil.

The 8- $\mathbf{N}_{3}$ precursor to $\mathbf{1 6}$ was prepared by dissolving $8(3.30 \mathrm{~g}, 1.88 \mathrm{mmol})$ in $38 \mathrm{~mL}$ DMF, followed by the addition of $\mathrm{NaN}_{3}(611 \mathrm{mg}, 9.40 \mathrm{mmol})$. The reaction mixture was heated to $35{ }^{\circ} \mathrm{C}$ and allowed to stir for $12 \mathrm{~h}$ before the DMF was removed via rotary evaporator. Heating past $35^{\circ} \mathrm{C}$ was avoided as it leads to degradation of the product. Then, $150 \mathrm{~mL}$ of EtOAc was added to the residue and extracted with water $(2 \times 100 \mathrm{~mL})$ and brine $(1 \times 100 \mathrm{~mL})$. The organic layer was dried with $\mathrm{Na}_{2} \mathrm{SO}_{4}$ and concentrated under vacuum. Compound $\mathbf{1 6}$ was obtained (3.20 g, 1.86 mmol, 99\%) as a yellow oil.

Under an $\mathrm{N}_{2}$ atmosphere, dry DMF (38 mL), PMDETA (29.8 mg, $\left.0.172 \mathrm{mmol}, 0.0359 \mathrm{~mL}\right)$, and Na ascorbate (68.1 $\mathrm{mg}, 0.344 \mathrm{mmol})$ were added to a mixture of $\mathbf{8}$-alkyne $(2.75 \mathrm{~g}, 1.72 \mathrm{mmol})$ and $\mathbf{8}-\mathbf{N}_{\mathbf{3}}(3.20 \mathrm{~g}, 1.86 \mathrm{mmol})$ in an oven-dried and sealed $250 \mathrm{~mL}$ round-bottom flask. $\mathrm{CuBr}(12.3 \mathrm{mg}, 0.0859 \mathrm{mmol})$ was then added and the reaction mixture was warmed to $50{ }^{\circ} \mathrm{C}$ and left to react for $2 \mathrm{~h}$. After completion, DMF was removed under reduced pressure. $5 \mathrm{~mL}$ of DCM was added to the resulting viscous mixture which was then loaded carefully onto a column. Column chromatography (100\% DCM to $8 \% \mathrm{MeOH} / \mathrm{DCM})$ yielded the product $(3.15 \mathrm{~g}, 0.949 \mathrm{mmol}, 51 \%$ yield from 8 ) as a yellow oil. ${ }^{1} \mathrm{H}$ NMR $\left(500 \mathrm{MHz}, \mathrm{CDCl}_{3}\right): \delta(\mathrm{ppm}) 7.68(\mathrm{~s}, 15 \mathrm{H}), 5.91(\mathrm{ddt}, J=16.3,10.9,5.8 \mathrm{~Hz}, 1 \mathrm{H}), 5.75-5.68$ (overlap, 15H), 5.34-5.23 (m, 1H), 5.19-5.11 (overlap, 31H), 4.69-4.57 (overlap, 46H), 4.44-4.40 (overlap, 16H), 4.25 (d, $J=1.7 \mathrm{~Hz}, 2 \mathrm{H}), 4.12-4.09$ (m, 1H), 4.08-3.99 (overlap, 15H), 3.92-3.84 (overlap, 30H), 3.71-3.62 (overlap, 5H), 3.58-3.48 (m, 27H), $3.45(\mathrm{dd}, J=10.5,4.6 \mathrm{~Hz}, 1 \mathrm{H}), 3.35(\mathrm{~m}, 1 \mathrm{H}), 1.07(\mathrm{~s}, 21 \mathrm{H}) .{ }^{13} \mathrm{C} \mathrm{NMR}\left(125 \mathrm{MHz}, \mathrm{CDCl}_{3}\right)$ : 
$\delta(\mathrm{ppm}) 143.4,133.9,133.5,133.4,123.9,116.7,102.2,87.5,76.1,75.5,70.4,69.4,68.2,67.3,64.0,58.7,53.3$, $51.0,50.7,31.9,17.9,10.4$.

\section{5) Thiol-ene functionalization of allyl-IEG 16-mer}

a) $16 b$

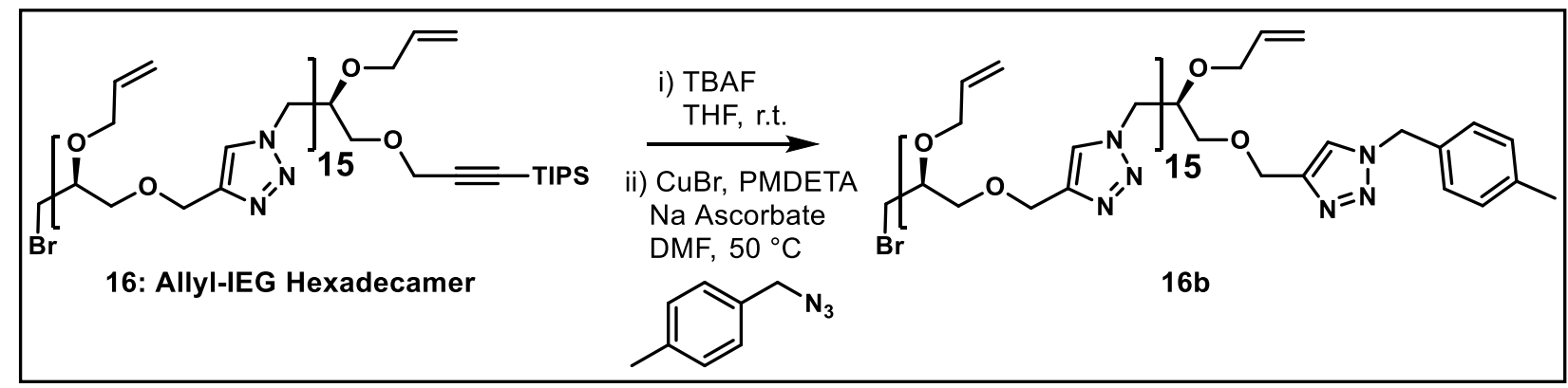

16b: 16 (2.00 g, $0.604 \mathrm{mmol})$ was dissolved in THF (12 mL), followed by the slow addition of TBAF (1M in THF, 1.05 equiv, $0.634 \mathrm{~mL}$ ). After the reaction has gone to completion, THF was removed under reduced pressure. Next, the crude product mixture was purified by column chromatography $(8 \% \mathrm{MeOH} / \mathrm{DCM})$ to yield 16-alkyne (1.80 g, $0.569 \mathrm{mmol}, 94.3 \%$ yield) as a yellow oil.

Under an $\mathrm{N}_{2}$ atmosphere, dry DMF $(5.4 \mathrm{~mL})$ and $\mathrm{Na}$ ascorbate $(5.3 \mathrm{mg}, 0.0269 \mathrm{mmol})$ were added to a mixture of 16-alkyne ( $850 \mathrm{mg}, 0.269 \mathrm{mmol})$ and 4-methylbenzyl azide $(158 \mathrm{mg}, 1.08 \mathrm{mmol})$ in an oven-dried and sealed 40 $\mathrm{mL}$ scintillation vial. A DMF solution of $0.1 \mathrm{M} \mathrm{CuBr}$ and $0.2 \mathrm{M}$ PMDETA $(0.135 \mathrm{~mL})$ was then added to the reaction mixture. The reaction was warmed to $50{ }^{\circ} \mathrm{C}$ and left to react for $2 \mathrm{~h}$. After completion, DMF was removed under reduced pressure. $1 \mathrm{~mL}$ of DCM was added to the resulting viscous mixture which was then loaded carefully onto a column. Column chromatography (100\% DCM to $8 \% \mathrm{MeOH} / \mathrm{DCM}$ ) yielded the product (806 $\mathrm{mg}, 0.243 \mathrm{mmol}$, 90.6\% yield from 16) as a yellow oil. ${ }^{1} \mathrm{H}$ NMR $\left(500 \mathrm{MHz}, \mathrm{CDCl}_{3}\right)$ : $\delta(\mathrm{ppm}) 7.68(\mathrm{~s}, 14 \mathrm{H}), 7.66(\mathrm{~s}, 1 \mathrm{H}), 7.47(\mathrm{~s}, 1 \mathrm{H})$, 7.18 (s, 4H), 5.90 (ddt, $J=16.1,10.2,5.4 \mathrm{~Hz}, 1 \mathrm{H}), 5.75-5.68$ (overlap, 15H), 5.49 (s, 2H), 5.31-5.23 (m, 1H), 5.195.11 (overlap, 31H), 4.69-4.57 (m, 48H), 4.44-4.40 (m, 16H), 4.12 (m, 1H), 4.06-3.98 (m, 15H), 3.92-3.84 (overlap, $30 \mathrm{H}), 3.70(\mathrm{dd}, J=9.5,4.9 \mathrm{~Hz}, 1 \mathrm{H}), 3.67-3.62$ (overlap, $2 \mathrm{H}$ ), 3.59-3.50 (overlap, $31 \mathrm{H}), 3.45$ (dd, $J=10.6,4.8 \mathrm{~Hz}$, $1 \mathrm{H}), 2.34(\mathrm{~s}, 3 \mathrm{H})$. 


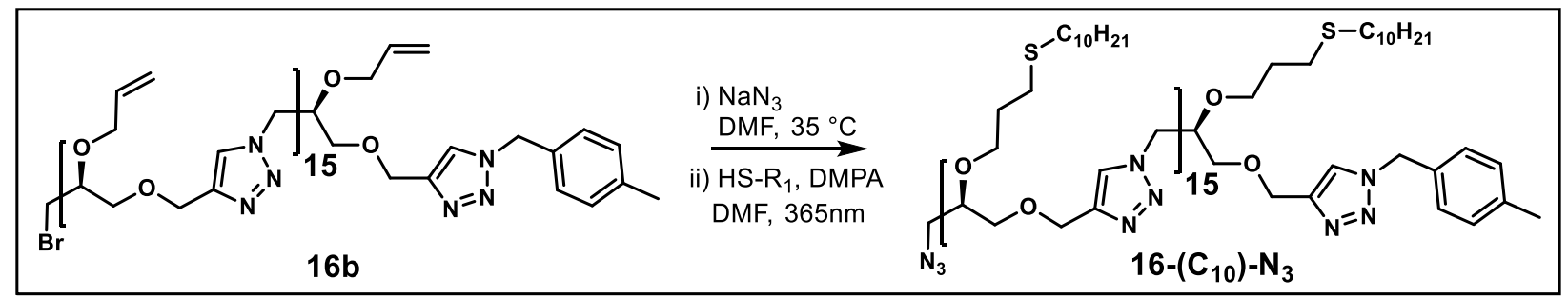

16- $\left(\mathbf{C}_{10}\right)-\mathbf{N}_{3}$ : Under an $\mathrm{N}_{2}$ atmosphere, dry DMF (11.2 $\mathrm{mL}$ ) was added to $\mathbf{1 6 b}$ (800 $\left.\mathrm{mg}, 0.253 \mathrm{mmol}\right)$, followed by the addition of $\mathrm{NaN}_{3}(98.7 \mathrm{mg}, 1.52 \mathrm{mmol})$. The reaction mixture was heated to $35{ }^{\circ} \mathrm{C}$ and allowed to stir for $12 \mathrm{~h}$ before the DMF was removed via a rotary evaporator. Then, $50 \mathrm{~mL}$ of EtOAc was added to the residue and the mixture was extracted with water $(2 \times 30 \mathrm{~mL})$ and brine $(1 \times 30 \mathrm{~mL})$. The organic layer was dried with $\mathrm{Na}_{2} \mathrm{SO}_{4}$ and concentrated under vacuum yielding $\mathbf{1 6} \mathbf{b}-\mathbf{N}_{3}$.

16b-N $\mathbf{N}_{\mathbf{3}}(743 \mathrm{mg}, 0.235 \mathrm{mmol})$ was dissolved in a solution of DMF (12.7 mL), 1-decanethiol $(5.24 \mathrm{~g}, 30.08 \mathrm{mmol}$, $6.36 \mathrm{~mL})$, and 2,2-dimethoxy-2-phenylacetophenone $(241 \mathrm{mg}, 0.94 \mathrm{mmol})$ in a $40 \mathrm{~mL}$ scintillation vial. The solution was sparged with $\mathrm{N}_{2}$, and then subjected to $365 \mathrm{~nm}$ light for $2 \mathrm{~h}$. The solution was then dialyzed in 3.5k MWCO dialysis tubing from Spectrum Labs in EtOH $(3 \times 500 \mathrm{~mL})$ over $12 \mathrm{~h}$. The EtOH was changed after $1 \mathrm{~h}$ and $3 \mathrm{~h}$ of dialysis. The dialyzed product was concentrated under vacuum and transferred to a $40 \mathrm{~mL}$ scintillation vial.

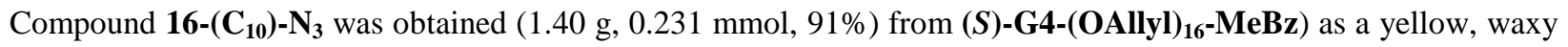
solid. ${ }^{1} \mathrm{H}$ NMR $\left(500 \mathrm{MHz}, \mathrm{CDCl}_{3}\right): \delta(\mathrm{ppm}) 7.67(\mathrm{~s}, 15 \mathrm{H}), 7.49(\mathrm{~s}, 1 \mathrm{H}), 7.18(\mathrm{~s}, 4 \mathrm{H}), 5.45(\mathrm{~s}, 2 \mathrm{H}), 4.71-4.54$ (overlap, 48H), 4.46-4.38 (overlap, 16H), 3.89-3.81 (overlap, 16H), 3.69-3.50 (overlap, 48H), 3.49-3.37 (overlap, 16H), 2.62-2.59 (overlap, 4H) 2.52-2.42 (br, 60H), 2.35 (s, 3H), 1.82-1.71 (overlap, 32H), 1.59-1.51 (br, 36H), 1.421.22 (br, 220H), 0.93-0.85 (br, 48H). ${ }^{13} \mathrm{C}$ NMR (125 MHz, $\left.\mathrm{CDCl}_{3}\right): \delta(\mathrm{ppm}) 144.0,129.6,128.0,124.2,68.7,68.6$, $64.6,53.8,53.1,51.3,39.5,32.3,31.9,31.8,29.8,29.7,29.6,29.5,29.4,29.2,28.8,28.5,28.3,22.5,22.3,21.0$, $18.3,18.0,14.0$. 


\section{6) Synthesis of diblock copolymers}

a) $32 a$

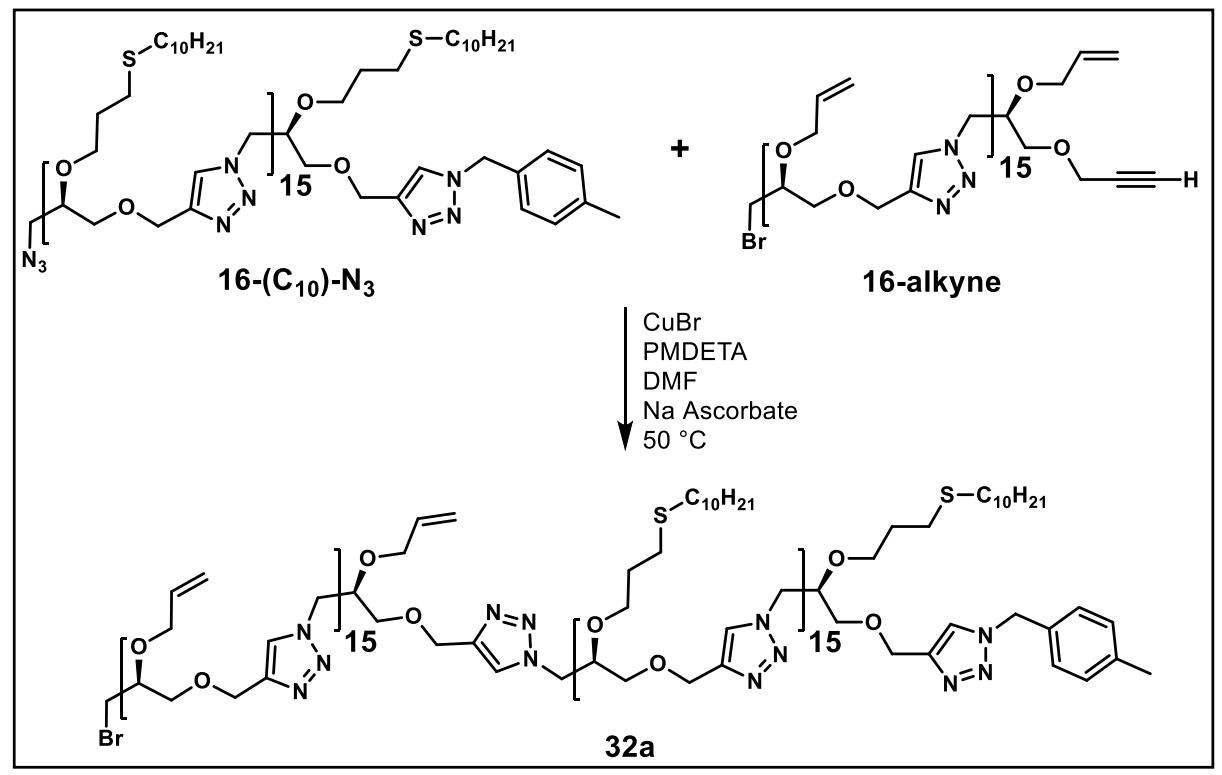

32a: Under an $\mathrm{N}_{2}$ atmosphere, dry DMF ( $\left.5 \mathrm{~mL}\right)$ and $\mathrm{Na}$ ascorbate $(4.5 \mathrm{mg}, 0.023 \mathrm{mmol})$ were added to a mixture of 16-( $\left.\mathbf{C}_{\mathbf{1 0}}\right)-\mathbf{N}_{\mathbf{3}}(1.39 \mathrm{~g}, 0.229 \mathrm{mmol})$ and 16-alkyne $(869 \mathrm{mg}, 0.275 \mathrm{mmol})$ in an oven-dried and sealed $40 \mathrm{~mL}$ scintillation vial. A DMF solution of $0.1 \mathrm{M} \mathrm{CuBr}$ and $0.2 \mathrm{M}$ PMDETA $(0.115 \mathrm{~mL})$ was then added to the reaction mixture. The reaction mixture was warmed to $50{ }^{\circ} \mathrm{C}$ and left to react for $2 \mathrm{~h}$. After completion, DMF was removed under reduced pressure. $2 \mathrm{~mL}$ of DCM was added to the resulting viscous mixture which was then loaded carefully onto a column. Column chromatography (100\% DCM to $8 \% \mathrm{MeOH} / \mathrm{DCM})$ yielded the product (1.02 g, 0.110 mmol, $48 \%$ yield from $\left.\mathbf{1 6}-\left(\mathbf{C}_{\mathbf{1 0}}\right)-\mathbf{N}_{\mathbf{3}}\right)$ as a yellow solid. ${ }^{1} \mathrm{H} \mathrm{NMR}\left(500 \mathrm{MHz}, \mathrm{CDCl}_{3}\right): \delta(\mathrm{ppm})$ 7.70-7.65 (overlap, 31H), 7.48 (s, 1H), 7.19 (s, 4H), 5.90 (ddt, $J=16.4,11.0,5.7 \mathrm{~Hz}, 1 \mathrm{H}), 5.76-5.67$ (overlap, $15 \mathrm{H}), 5.49$ (s, 2H), 5.32$5.26(\mathrm{~m}, 1 \mathrm{H}), 5.20-5.10$ (overlap, 31H), 4.71-4.55 (overlap, 96H), 4.46-4.44 (overlap, 32H), 4.13-4.08 (m, 1H), 4.13-3.99 (overlap, 15H), 3.91-3.80 (overlap, 48H), 3.70 (dd, $J=9.7,5.0 \mathrm{~Hz}, 1 \mathrm{H}$ ), 3.72-3.50 (overlap, 79H), 3.453.37 (overlap, 16H), 2.68-2.55 (overlap, 4H), 2.50-2.41 (overlap, 60H), 2.35 (s, 3H), 1.99-1.92 (m, 2H), 1.79-1.70 (overlap, 32H), 1.57-1.49 (overlap, 30H), 1.38-1.15 (overlap, 224H), 0.89-0.83 (overlap, 48H). ${ }^{13} \mathrm{C} \mathrm{NMR} \mathrm{(125} \mathrm{MHz,}$ $\left.\mathrm{CDCl}_{3}\right): \delta(\mathrm{ppm}) 144.2,134.0,129.9,128.3,124.5,117.7,77.4,76.3,71.3,69.0,68.9,68.8,64.8,51.6,32.2,32.0$ 29.7, 29.6, 29.4, 29.0, 28.6, 22.7, 22.6, 14.2, 14.0. 


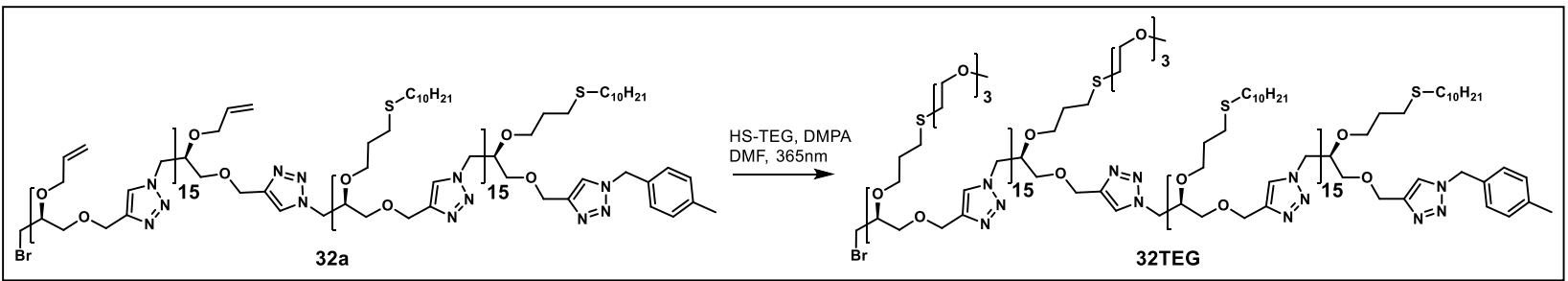

32TEG: 32a (725 mg, $0.0783 \mathrm{mmol})$ was dissolved in a mixture of DMF (3.6 mL), 1-mercapto-triethyleneglycol monomethyl ether ${ }^{1}(1.80 \mathrm{~g}, 0.316 \mathrm{mmol})$, and 2,2-dimethoxy-2-phenylacetophenone ( $\left.80.3 \mathrm{mg}, 0.313 \mathrm{mmol}\right)$ in a 40 $\mathrm{mL}$ scintillation vial. The solution was sparged with $\mathrm{N}_{2}$ and subjected to $365 \mathrm{~nm}$ light for $2 \mathrm{~h}$. The solution was then dialyzed in 8k MWCO dialysis tubing from Spectrum Labs in EtOH $(3 \times 300 \mathrm{~mL})$ over $12 \mathrm{~h}$. The product 32TEG (812 mg, $0.0671 \mathrm{mmol}, 86 \%$ yield) was concentrated under vacuum. ${ }^{1} \mathrm{H} \mathrm{NMR}\left(500 \mathrm{MHz}, \mathrm{CDCl}_{3}\right): \delta(\mathrm{ppm}) 7.70-7.64$ (overlap, 31H), 7.47 (s, 1H), 7.17 (s, 4H), 5.49 (s, 2H), 4.70-4.56 (overlap, 96H), 4.45-4.36 (overlap, 32H), 3.873.80 (br, 16H), 3.69-3.51 (overlap, 288H), 3.43-3.35 (br, 64H), 2.67-2.63 (t, $J=7.0 \mathrm{~Hz}, 32 \mathrm{H}$ ), 2.52-2.42 (overlap, $96 \mathrm{H}) 2.34(\mathrm{~s}, 3 \mathrm{H}), 1.79-1.70(\mathrm{br}, 32 \mathrm{H}), 1.68-1.62(\mathrm{br}, 36 \mathrm{H}) 1.56-1.48(\mathrm{p}, J=7.4 \mathrm{~Hz}, 28 \mathrm{H}), 1.37-1.12(\mathrm{br}, 224 \mathrm{H})$, 0.88-0.84 (t, 48H). ${ }^{13} \mathrm{C}$ NMR (125 MHz, $\left.\mathrm{CDCl}_{3}\right): \delta(\mathrm{ppm}) 143.9,129.6,128.0,124.2,77.1,71.7,70.7,70.4,70.3$, $70.1,64.5,58.8,51.3,31.9,31.7,31.1,29.6,29.5,29.4,29.1,29.1,28.8,28.7,28.3,22.5,18.3,14.0,1.8$.

c) $32 T G$

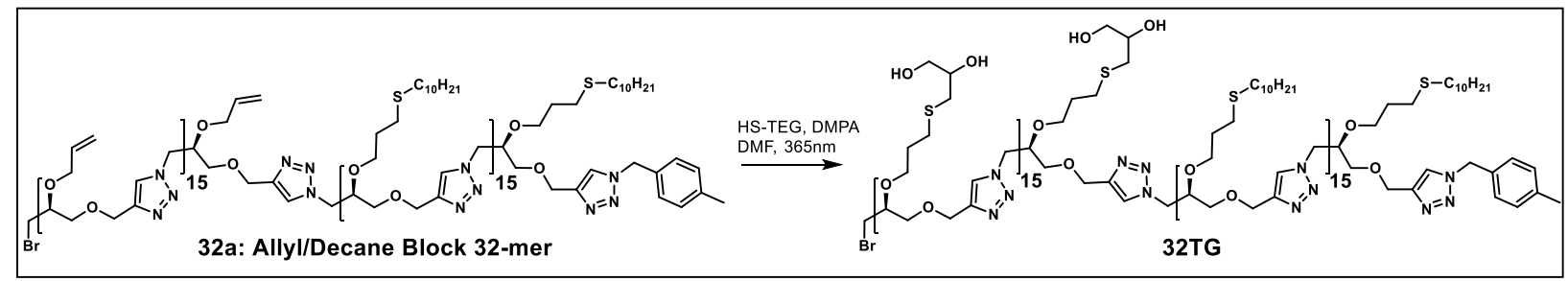

32TG: 32a (200 mg, $0.0217 \mathrm{mmol})$ was dissolved in a mixture of DMF $(0.600 \mathrm{~mL})$, racemic thioglycerol $(300 \mathrm{mg}$, $2.78 \mathrm{mmol})$, and 2,2-dimethoxy-2-phenylacetophenone $(22.2 \mathrm{mg}, 0.0868 \mathrm{mmol})$ in a $40 \mathrm{~mL}$ scintillation vial. The solution was sparged with $\mathrm{N}_{2}$ and subjected to $365 \mathrm{~nm}$ light for $2 \mathrm{~h}$. The solution was then dialyzed in 8k MWCO dialysis tubing from Spectrum Labs in EtOH $(3 \times 300 \mathrm{~mL})$ over $12 \mathrm{~h}$. The product 32TG $(198 \mathrm{mg}, 0.0181 \mathrm{mmol}$, $83 \%$ yield) was concentrated under vacuum. ${ }^{1} \mathrm{H}$ NMR (500 MHz, $\left(\mathrm{CD}_{3}\right)_{2} \mathrm{SO}$ ): $\delta(\mathrm{ppm})$ 8.08-8.00 (overlap, $32 \mathrm{H}$ ), $7.20(\mathrm{~d}, J=7.8 \mathrm{~Hz}, 1 \mathrm{H}), 7.15(\mathrm{~d}, J=7.9 \mathrm{~Hz}, 1 \mathrm{H}), 7.21-7.18(\mathrm{~d}, J=7.9 \mathrm{~Hz}, 2 \mathrm{H}), 7.16-7.13(\mathrm{~d}, J=7.9 \mathrm{~Hz}, 2 \mathrm{H}), 5.52$ 
(s, 2H), 4.80-4.72 (m, 16H), 4.62-4.48 (overlap, 112H), 4.43-4.32 (overlap, 32H), 3.87-3.78 (br, 16H), 3.58-3.45 (overlap, 128H), 3.34-3.24 (overlap, 64H), 2.57-2.52 (overlap, 16H) 2.42-2.23 (overlap, 116H), 1.74-1.67 (m, 2H), 1.63-1.51 (overlap, 66H), 1.46-1.38 (br, 28H), 1.30-1.12 (overlap, 220H), 1.11-0.96 (br, 4H), 0.86-0.73 (br, 48H). ${ }^{13} \mathrm{C}$ NMR (125 MHz, $\left.\left(\mathrm{CD}_{3}\right)_{2} \mathrm{SO}\right): \delta(\mathrm{ppm}) 143.5,128.3,127.3,125.0,76.8,71.4,69.0,68.1,64.6,63.9,61.0,50.8$, $35.2,35.0,31.5,29.6,29.2,28.9,28.5,22.2,14.1,13.7$.

\section{d) Acetyl32TG}

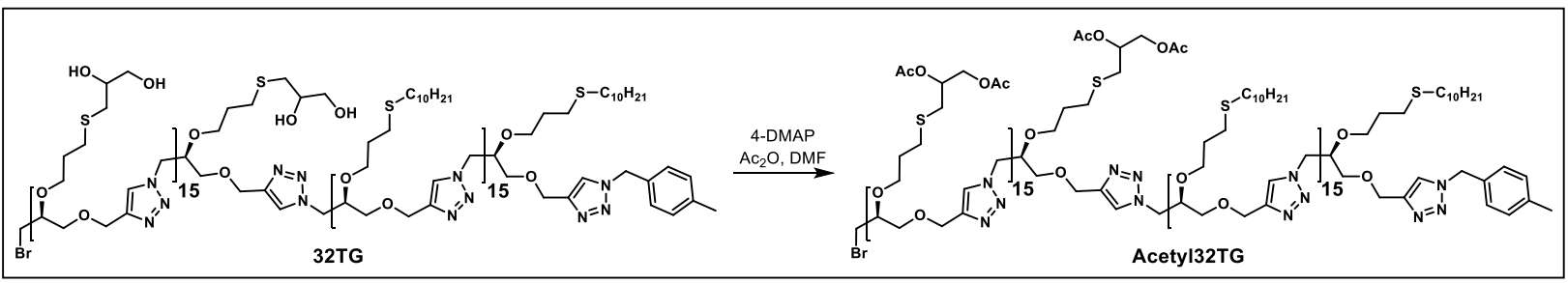

Acetyl32TG: 32TG (20 mg, $0.0018 \mathrm{mmol})$ was dissolved in DMF (2.0 mL). 4-DMAP (4.4 mg, $0.036 \mathrm{mmol})$ was added to the solution followed by acetic anhydride $(0.50 \mathrm{~mL}, 5.3 \mathrm{mmol})$. The reaction was left overnight, after which it was pushed through silica with $10 \% \mathrm{MeOH} / \mathrm{DCM}$ to remove 4-DMAP. The solution was then concentrated to obtain the product Acetyl32TG (10 mg, $0.0008 \mathrm{mmol}, 45 \%$ yield). ${ }^{1} \mathrm{H}$ NMR (500 $\mathrm{MHz}, \mathrm{CDCl}_{3}$ ): $\delta(\mathrm{ppm}) 7.73-$ 7.67 (overlap, 32H), 7.48 (br, 1H), 7.20-7.18 (br, 4H), 5.50 (s, 2H), 5.15-5.07 (br, 16H), 4.72-4.57 (overlap, 96H), 4.46-4.32 (overlap, 48H), 4.20-4.13 (overlap, 16H), 3.90-3.82 (overlap, 32H), 3.67-3.52 (overlap, 96H), 3.45-3.37 (br, 30H), 3.25 (br, 2H), 2.08 (br, 96H), 1.96-1.87 (br, 28H), 1.78-1.72 (br, 48H), 1.57-1.50 (br, 28H), 1.39-1.15 (overlap, 220H), 0.90-0.85 (br, 48H). 


\section{Section C. Spectroscopic Characterization}

\section{${ }^{1}$ H NMR Spectra}

a) Materials leading up to 1-alkyne and $1-N_{3}$

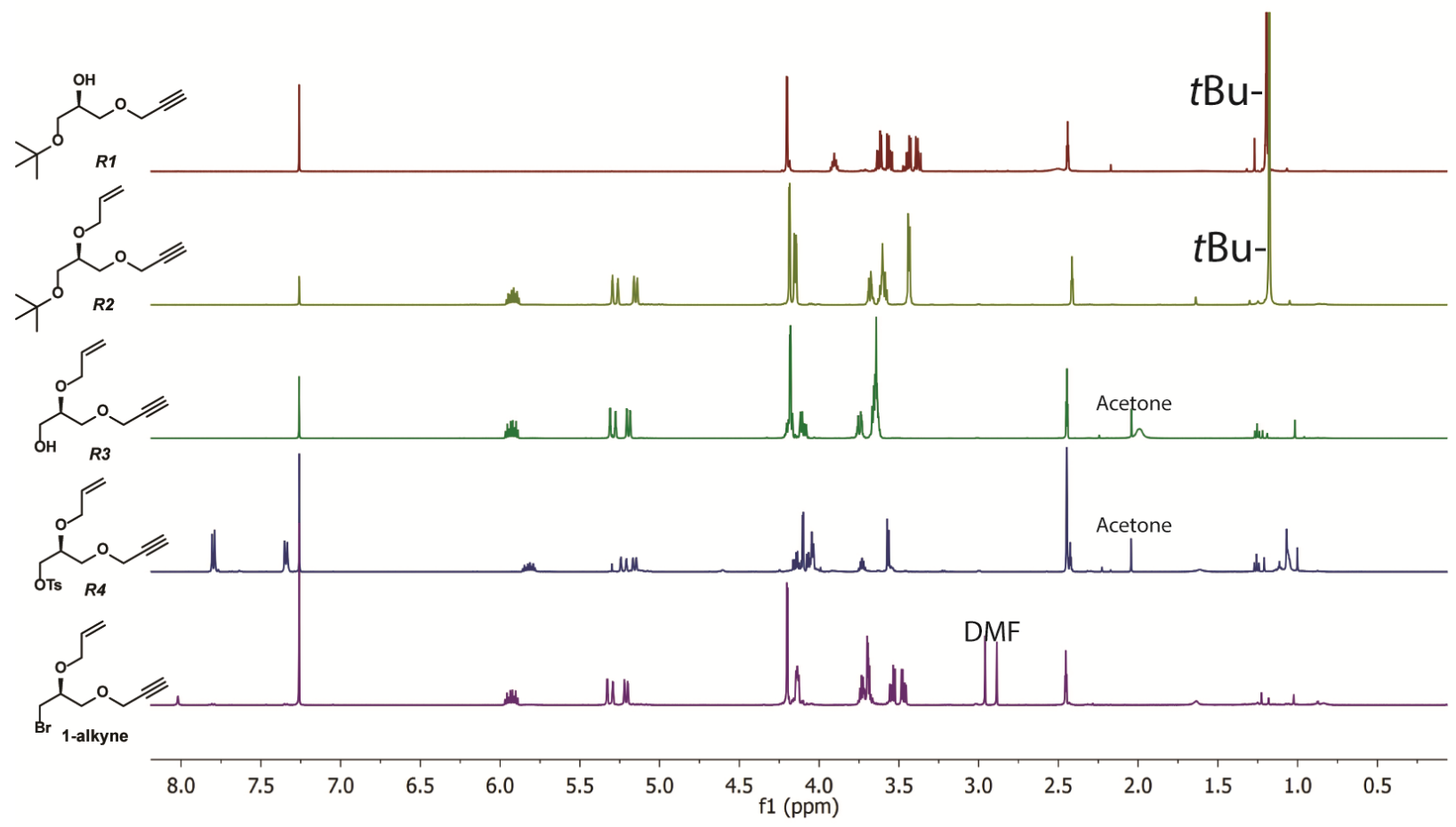

Figure S1. ${ }^{1}$ H NMR spectra of intermediates leading to 1-alkyne.

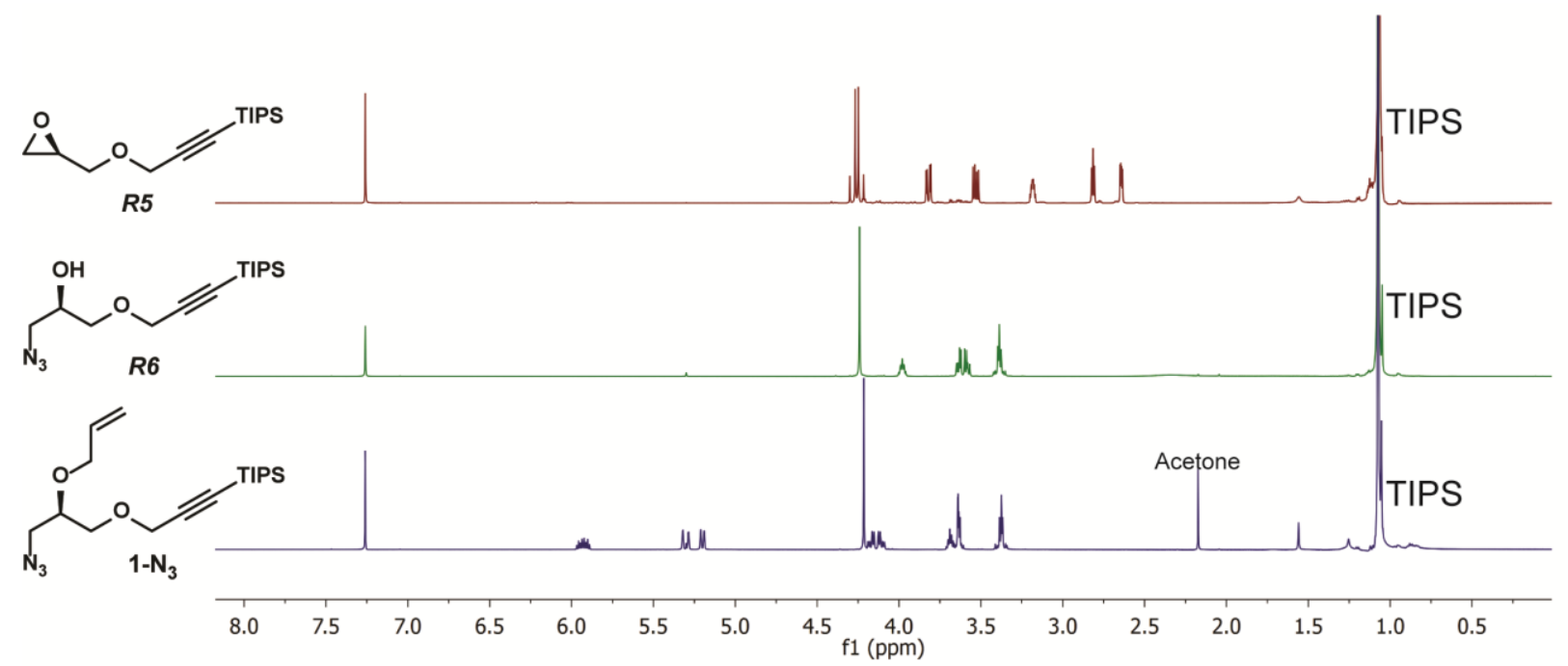

Figure S2. ${ }^{1} \mathrm{H}$ NMR spectra of intermediates leading to $\mathbf{1}-\mathbf{N}_{3}$. 


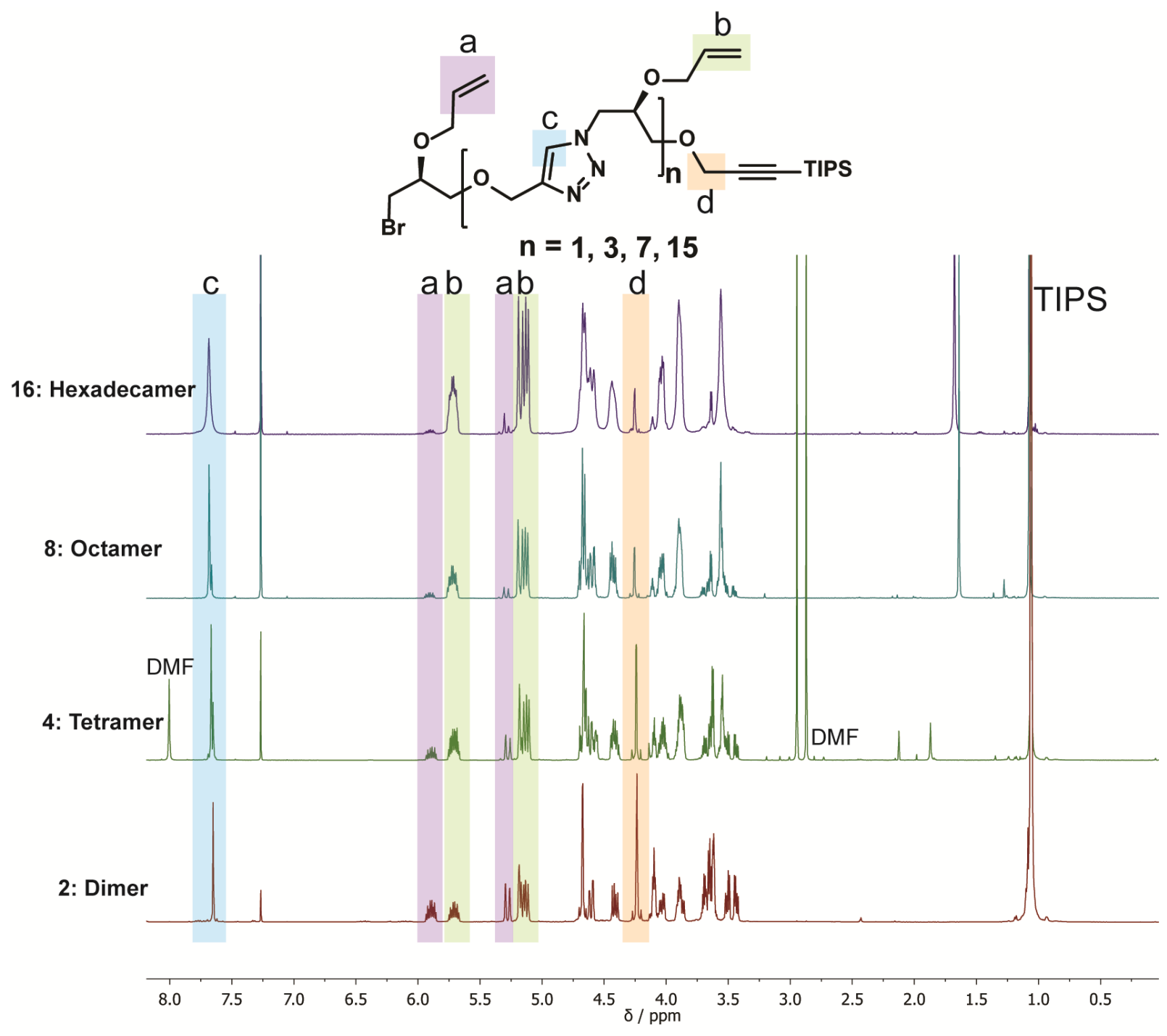

Figure S3. Comparison of ${ }^{1} \mathrm{H}$ NMR spectra of Allyl-IEG Oligomers Generations 1-4. 
c) $16 b$ and $16-\left(C_{10}\right)-N_{3}$
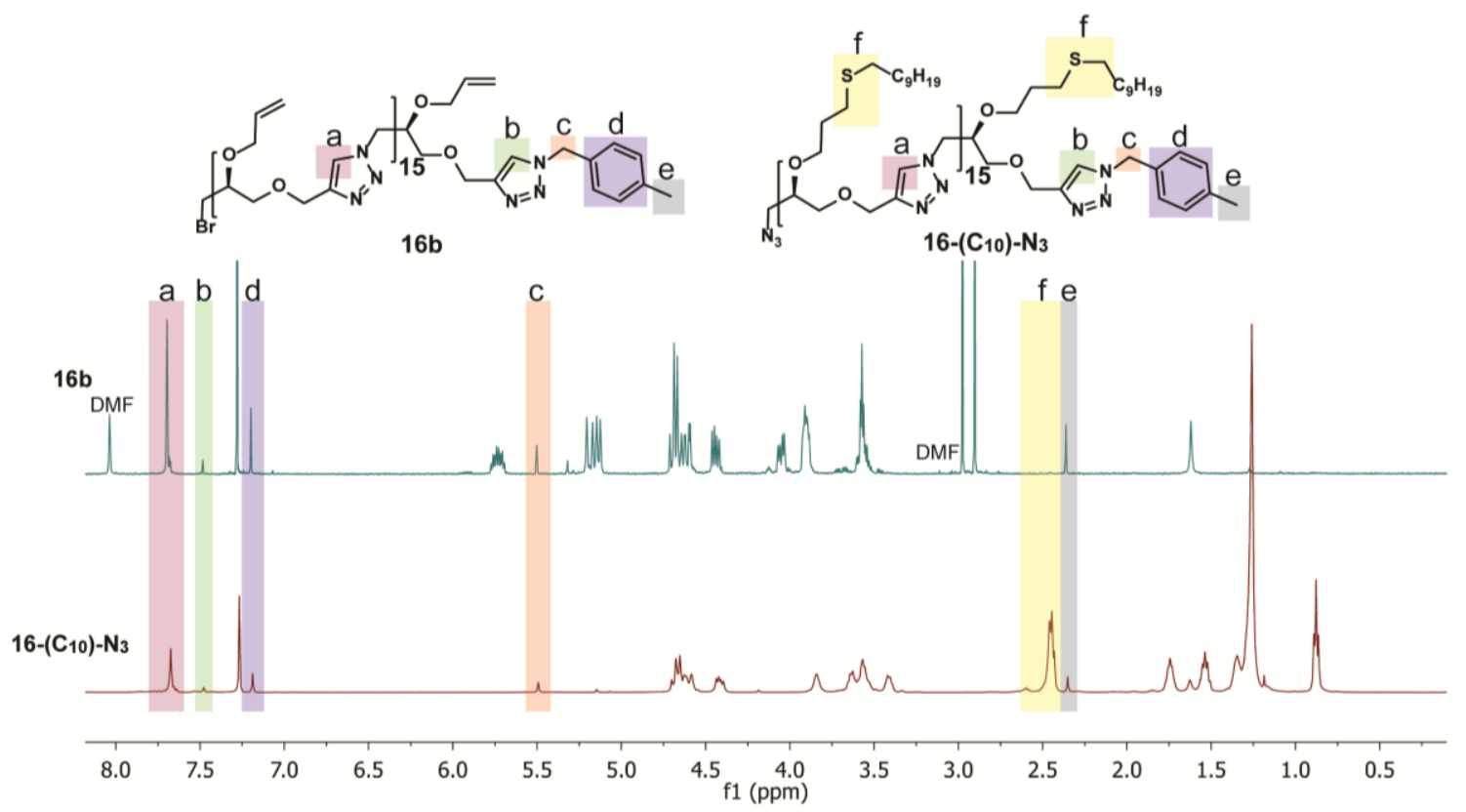

Figure S4. Comparison of ${ }^{1} \mathrm{H}$ NMR spectra of $\mathbf{1 6 b}$ and $\mathbf{1 6}-\left(\mathbf{C}_{\mathbf{1 0}}\right)-\mathbf{N}_{\mathbf{3}}$.

d) Diblock copolymers

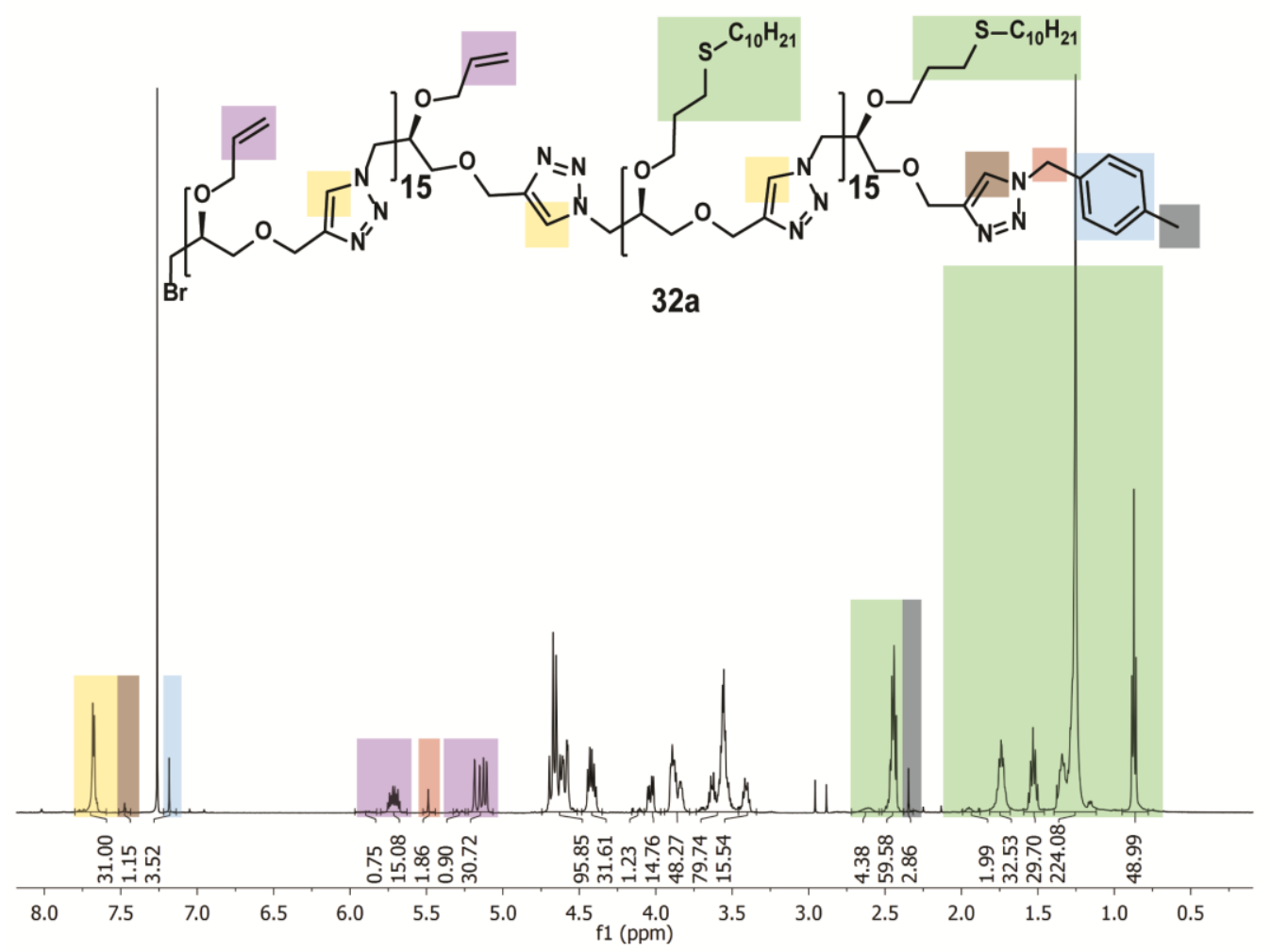

Figure S5. ${ }^{1} \mathrm{H}$ NMR spectrum of 32a: Allyl/Decane Block 32mer in $\mathrm{CDCl}_{3}$ 


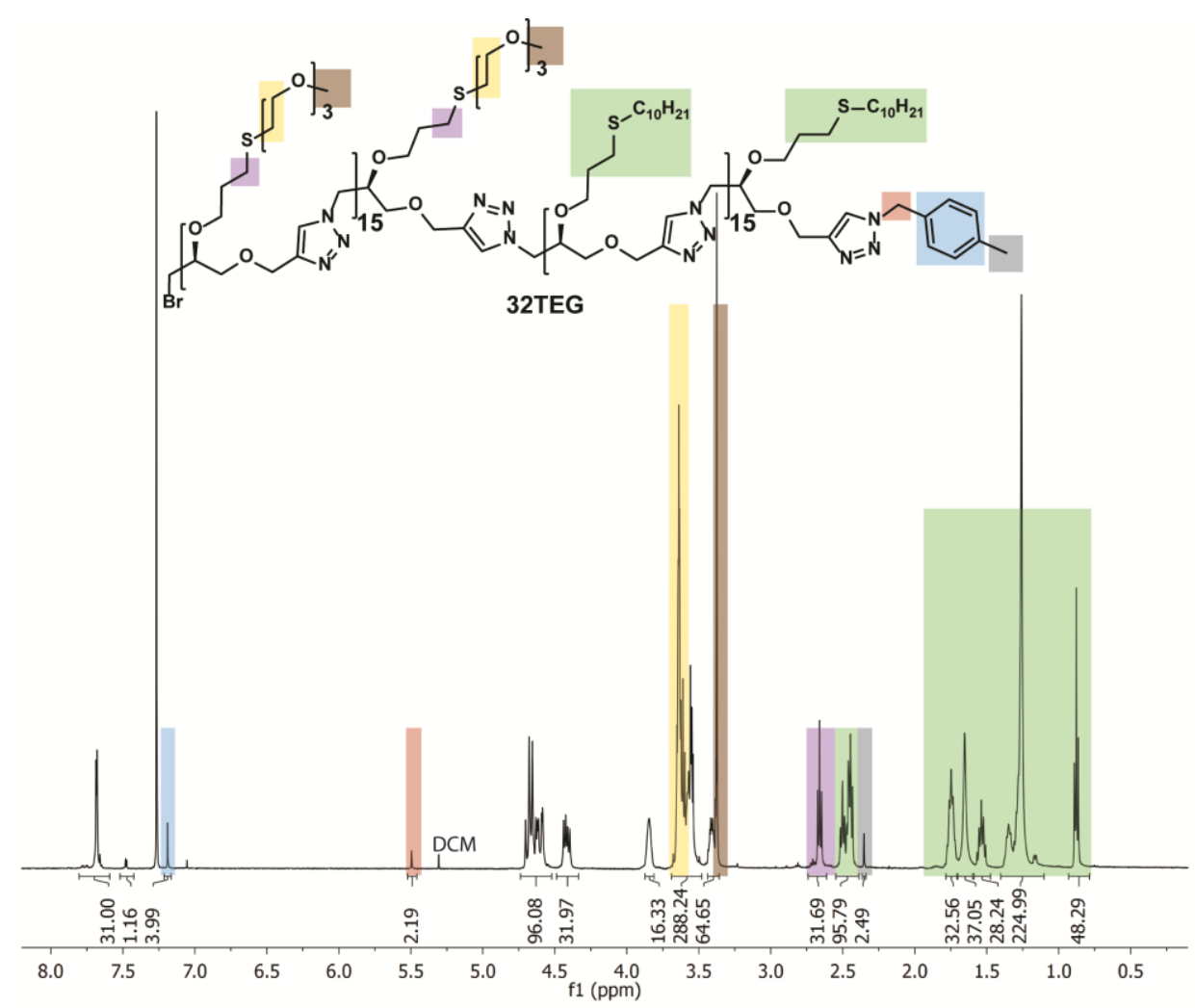

Figure S6. ${ }^{1} \mathrm{H}$ NMR spectrum of 32TEG: TEG/Decane Block 32mer in $\mathrm{CDCl}_{3}$

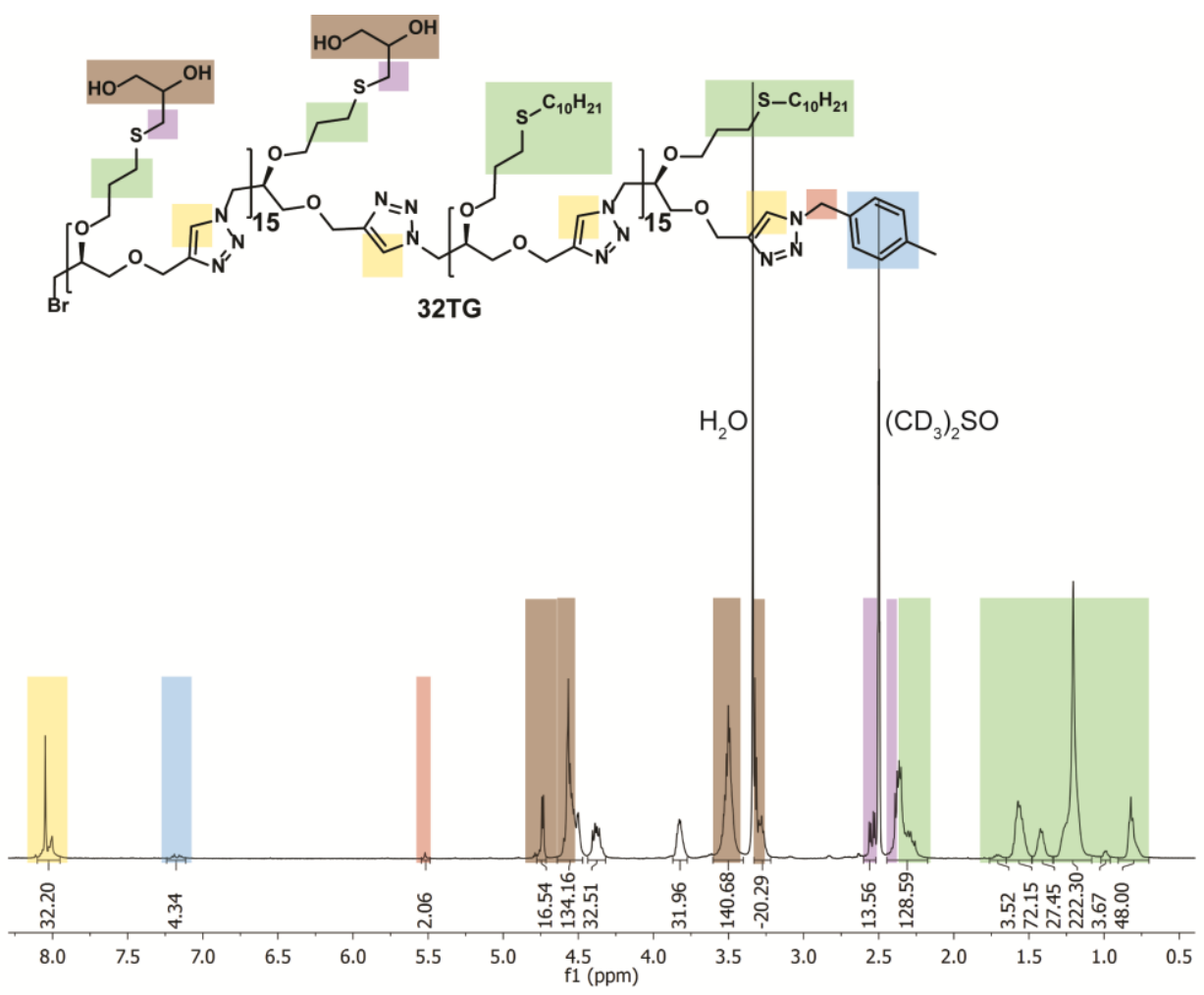

Figure S7. ${ }^{1} \mathrm{H}$ NMR spectrum of 32TG: TG/Decane Block 32mer in $\left(\mathrm{CD}_{3}\right)_{2} \mathrm{SO}$ 


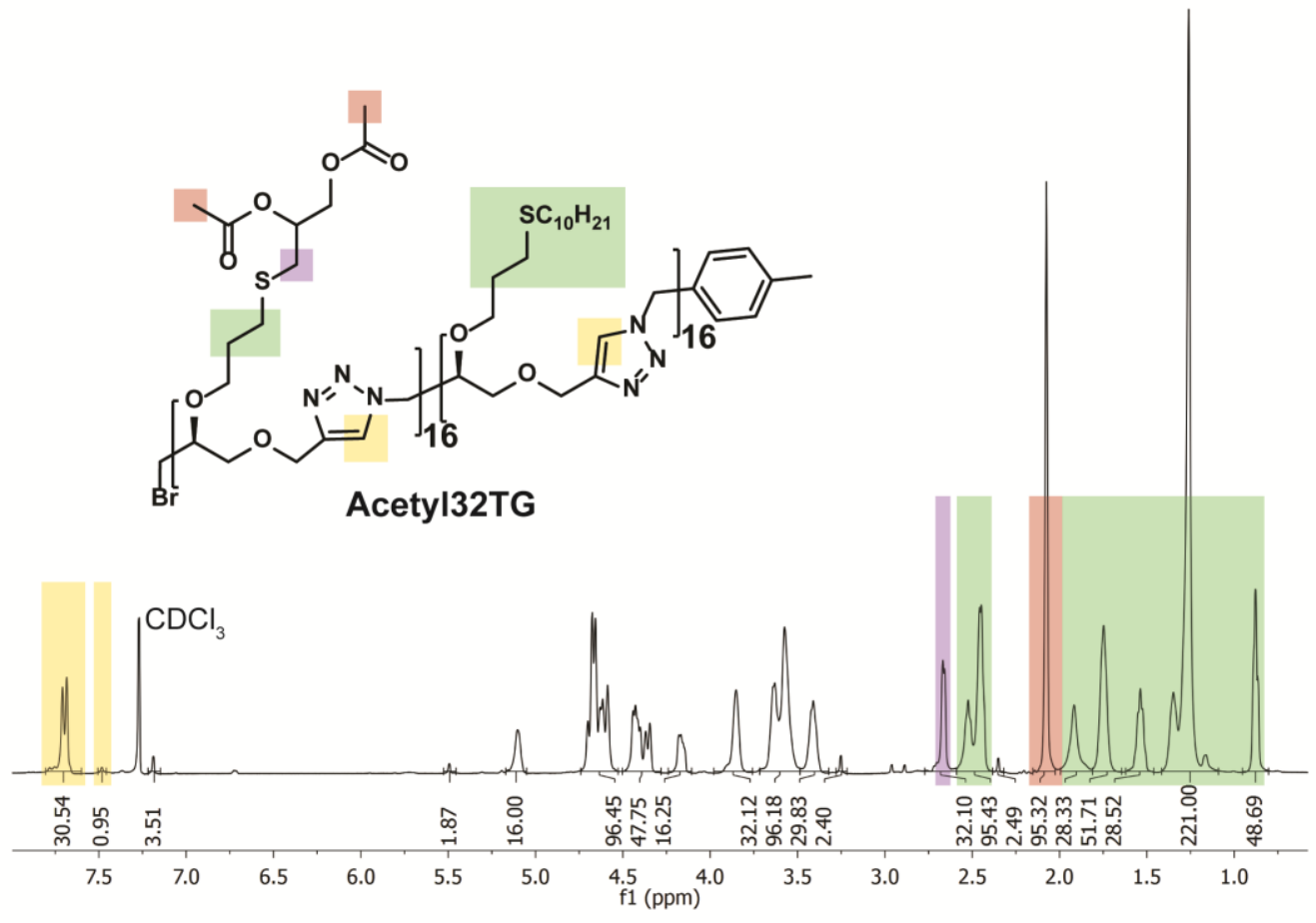

Figure S8. ${ }^{1} \mathrm{H}$ NMR spectrum of Acetyl32TG: Acetylated-TG/Decane Block 32mer in $\mathrm{CDCl}_{3}$ 


\section{${ }^{13}$ C NMR Spectra}

a) 4
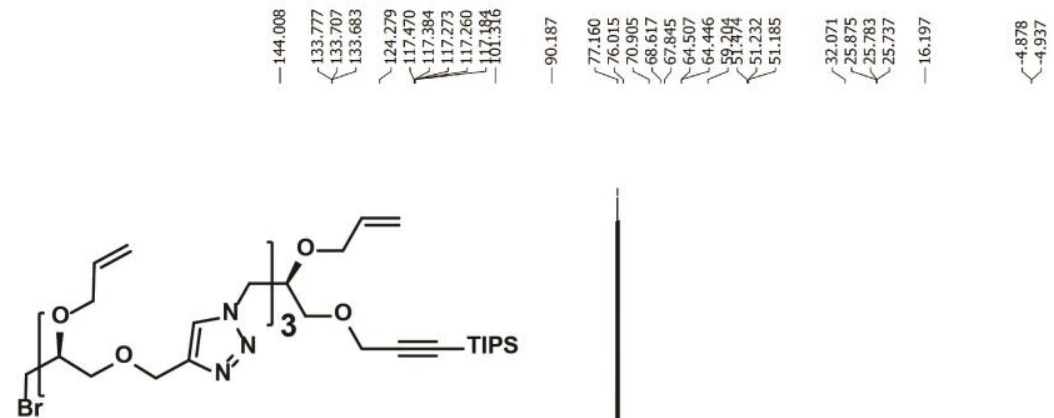

4: Allyl-IEG Tetramer

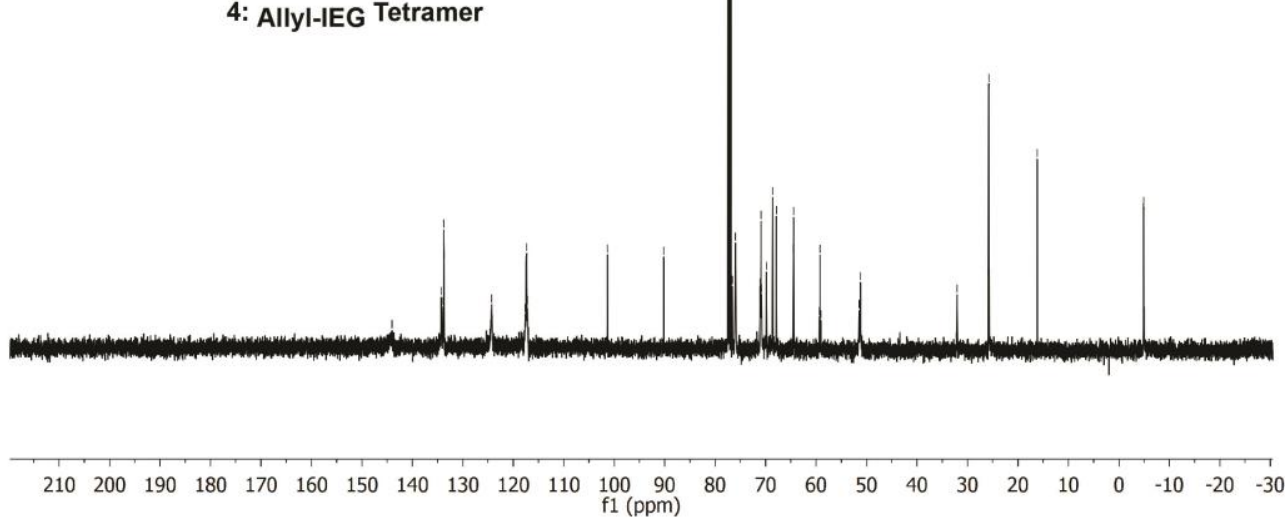

Figure S9. ${ }^{13} \mathrm{C}$ NMR spectrum of 4: Allyl-IEG Tetramer in $\mathrm{CDCl}_{3}$ 
b) 8

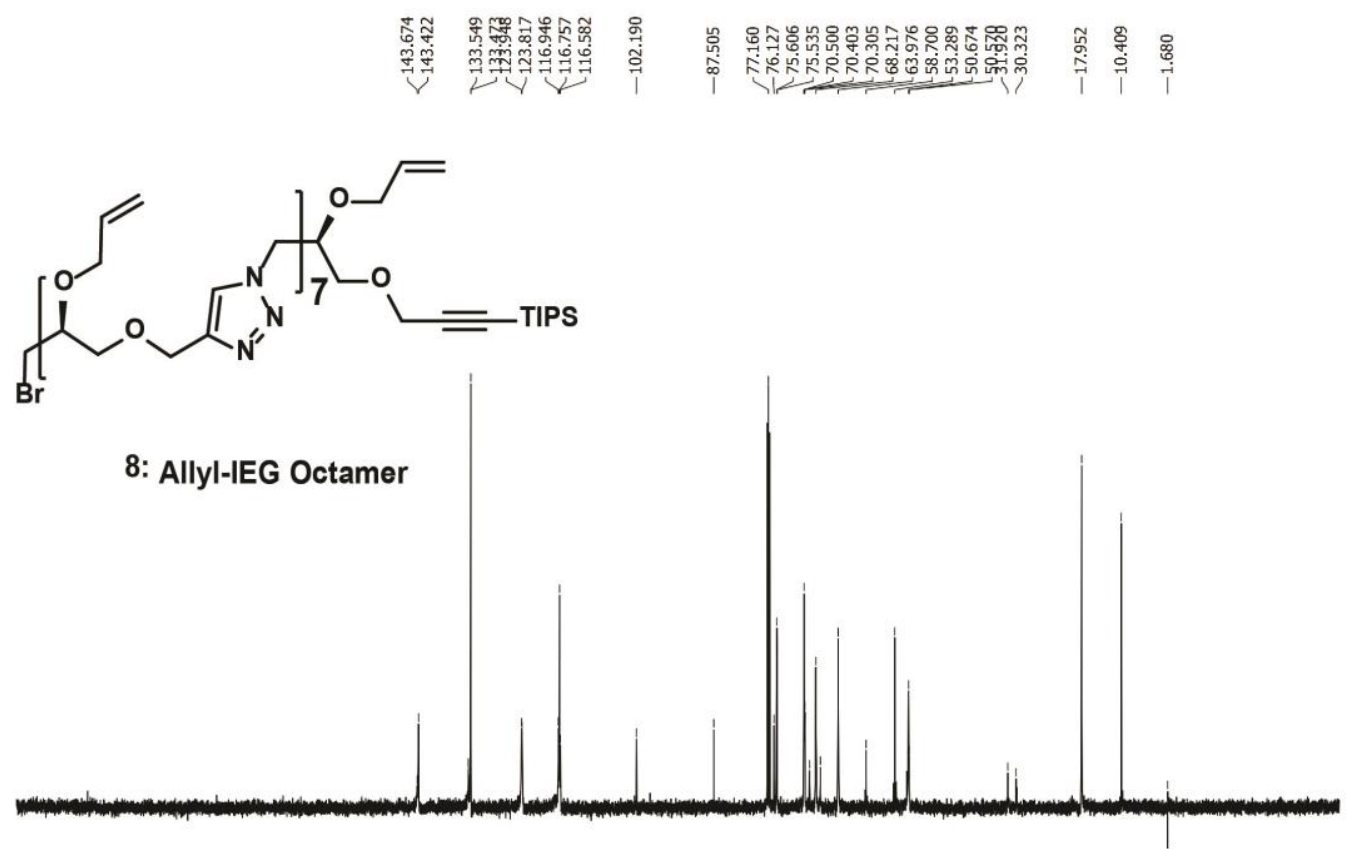

$\begin{array}{lllllllllllllllllllllllll}210 & 200 & 190 & 180 & 170 & 160 & 150 & 140 & 130 & 120 & 110 & \begin{array}{c}100 \\ \mathrm{f} 1(\mathrm{ppm})\end{array} & 80 & 70 & 60 & 50 & 40 & 30 & 20 & 10 & 0 & -10 & -20 & -30\end{array}$ Figure S10. ${ }^{13} \mathrm{C}$ NMR spectrum of 8 : Allyl-IEG Octamer in $\mathrm{CDCl}_{3}$

c) 16

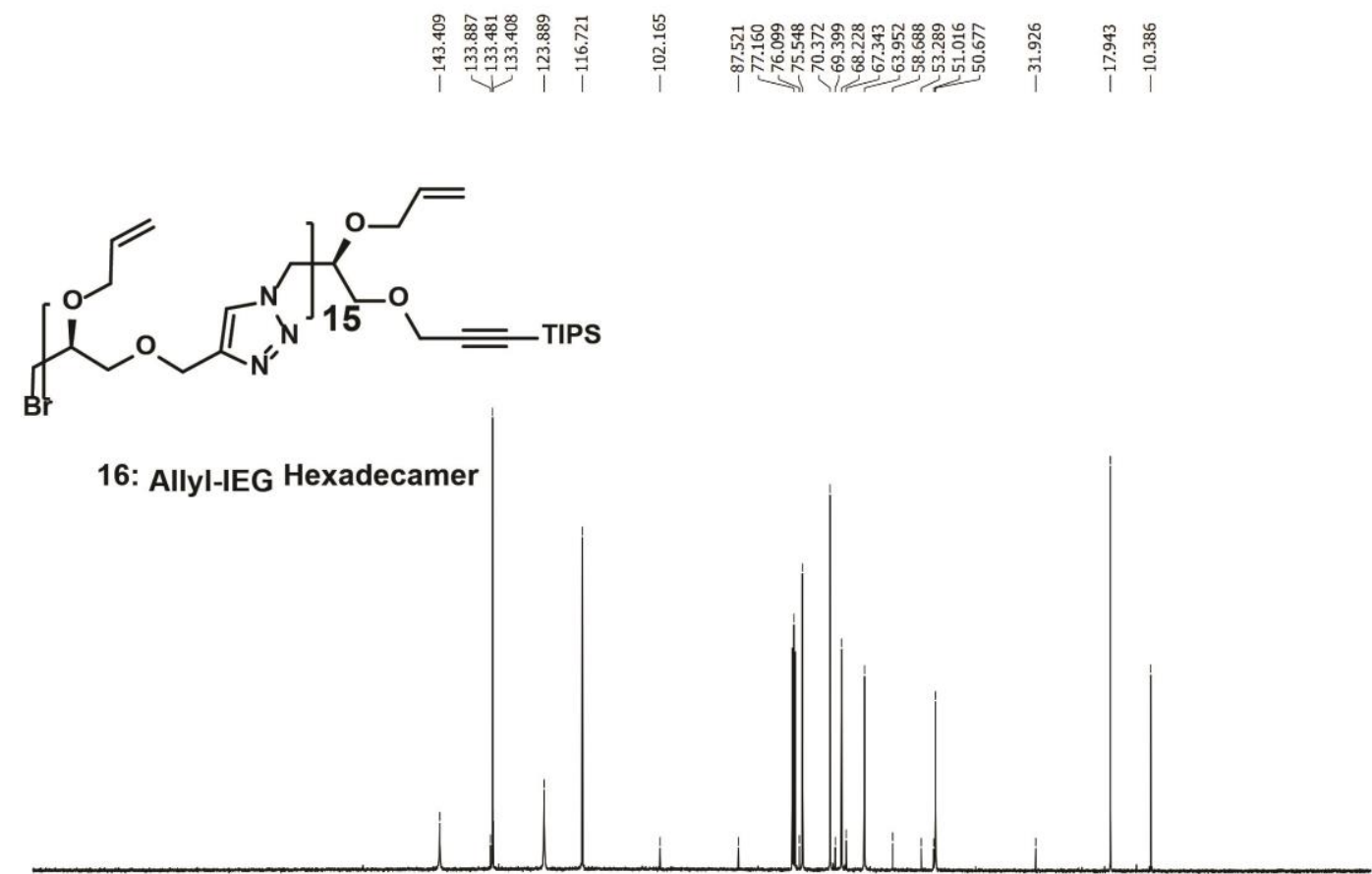

$\begin{array}{llllllllllllllllllllllllllllll}210 & 200 & 190 & 180 & 170 & 160 & 150 & 140 & 130 & 120 & 110 & \begin{array}{c}100 \\ \mathrm{f} 1(\mathrm{ppm})\end{array} & 90 & 70 & 60 & 50 & 40 & 30 & 20 & 10 & 0 & -10 & -20 & -30\end{array}$

Figure S11. ${ }^{13} \mathrm{C}$ NMR spectrum of 16: Allyl-IEG Hexadecamer in $\mathrm{CDCl}_{3}$ 
d) $16-\left(C_{10}\right)-N_{3}$
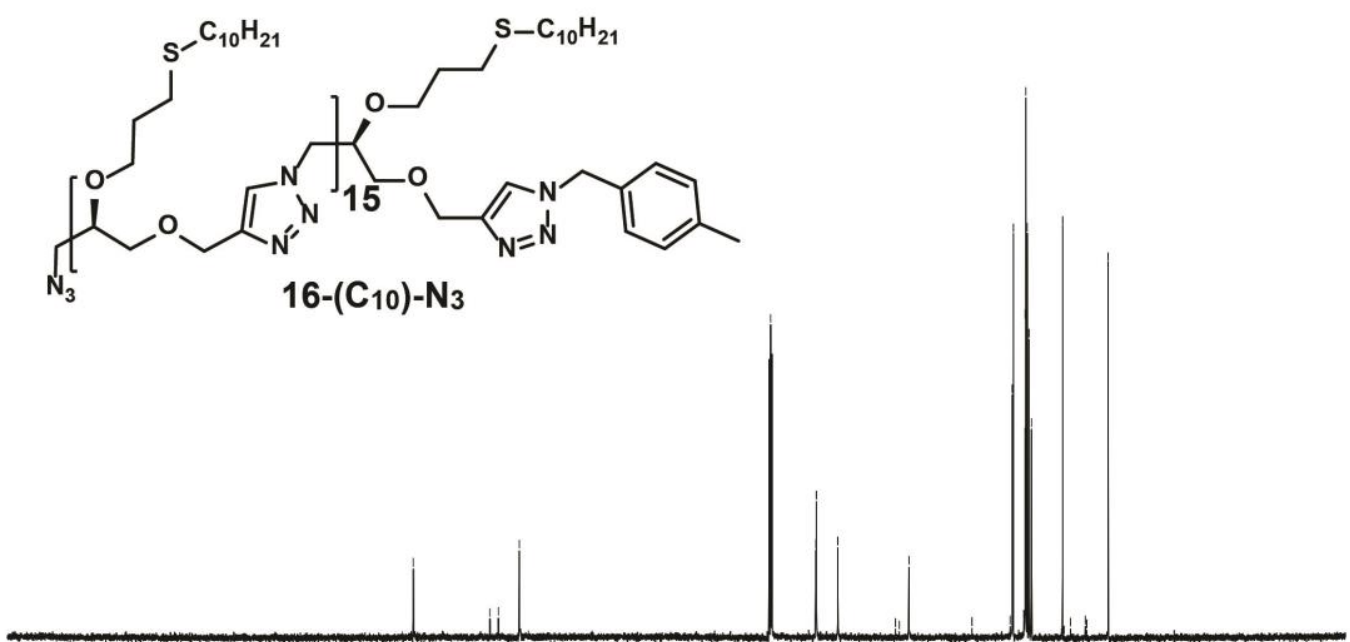

e) $32 a$

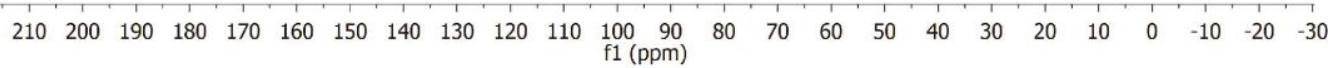

Figure S12. ${ }^{13} \mathrm{C}$ NMR spectrum of $\mathbf{1 6 -}\left(\boldsymbol{C}_{10}\right)-\mathrm{N}_{3}$ : Decane 16 mer in $\mathrm{CDCl}_{3}$
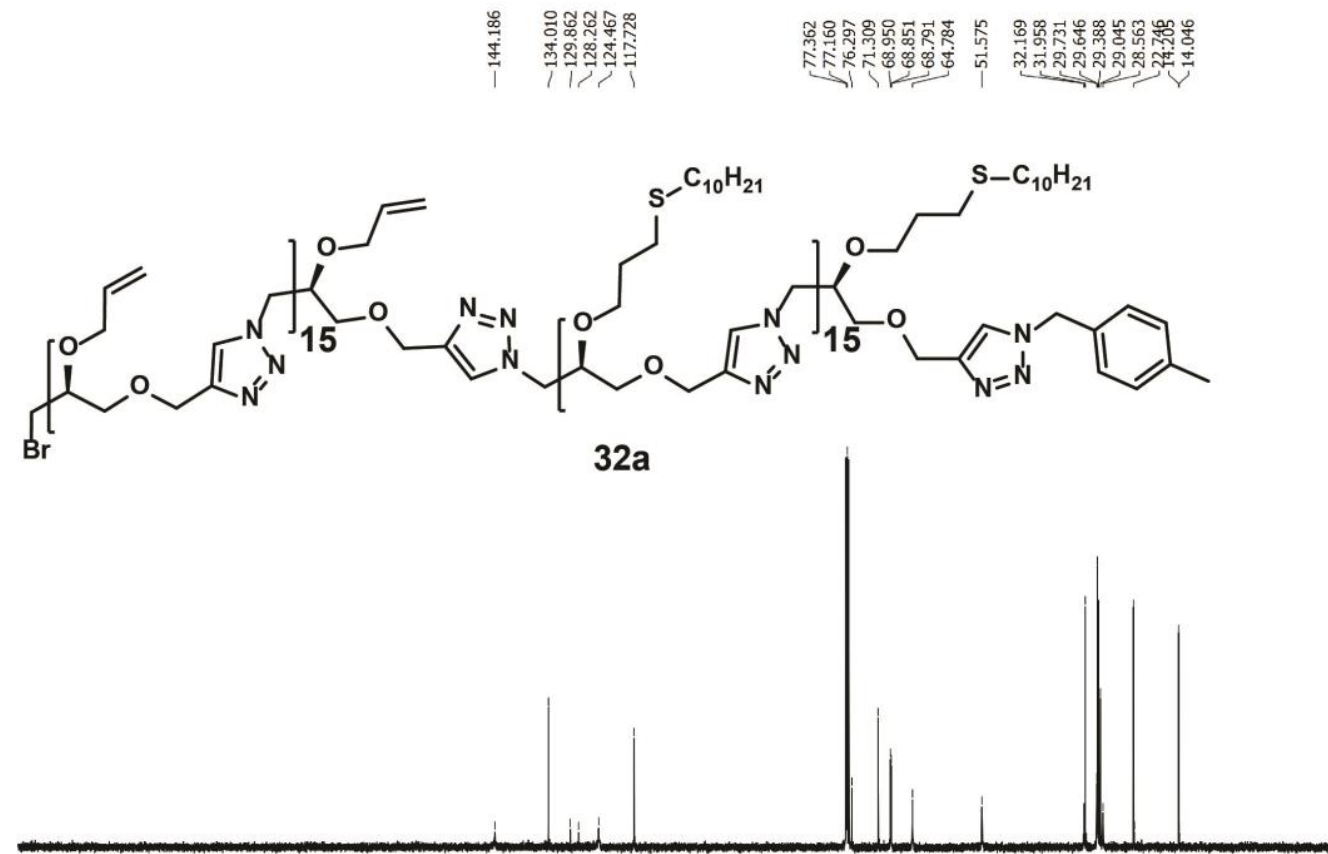

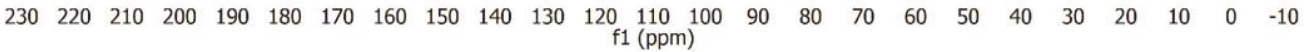

Figure S13. ${ }^{13} \mathrm{C}$ NMR spectrum of 32a: Allyl/Decane Block 32mer in $\mathrm{CDCl}_{3}$ 


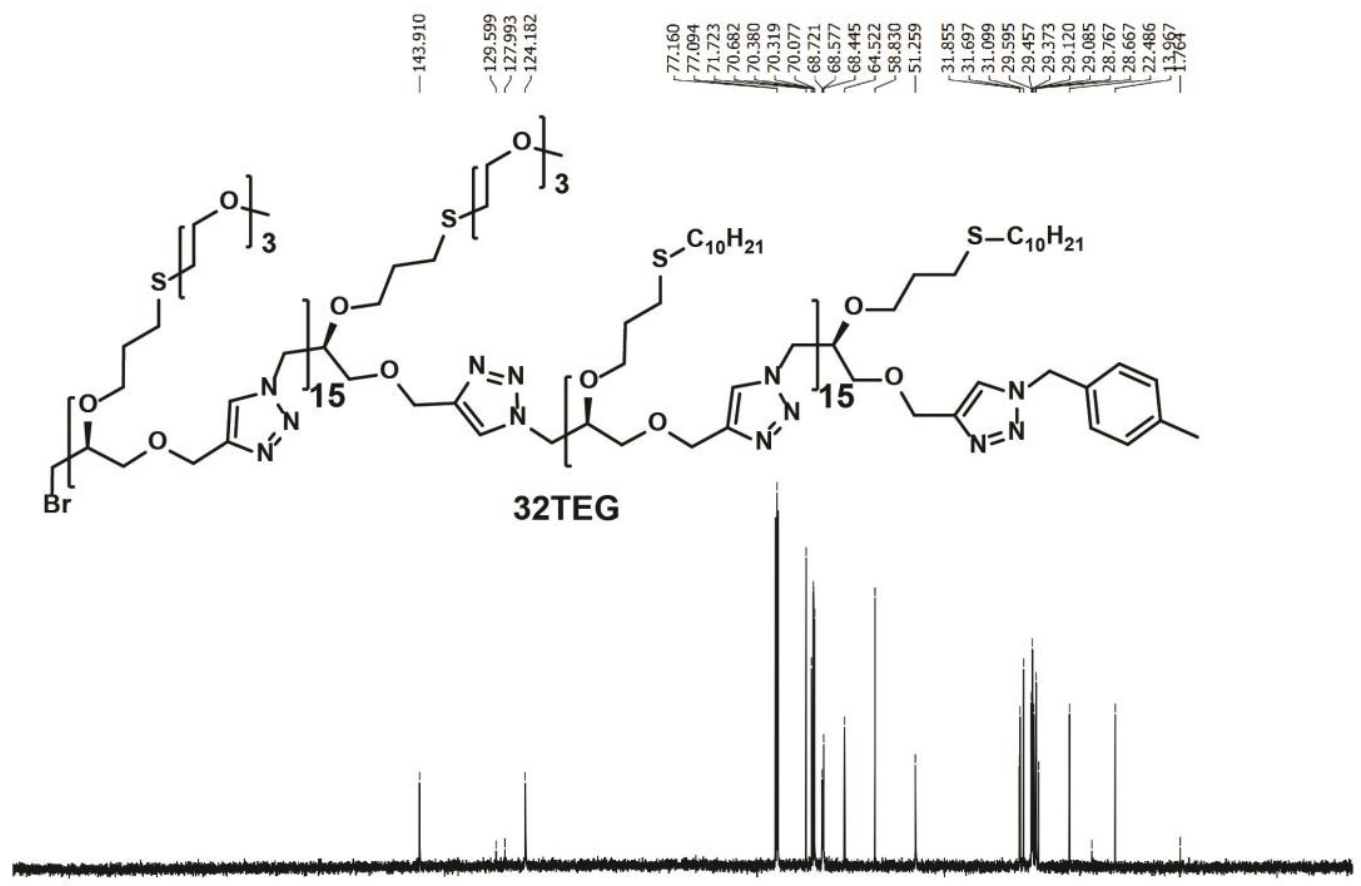

g) $32 T G$

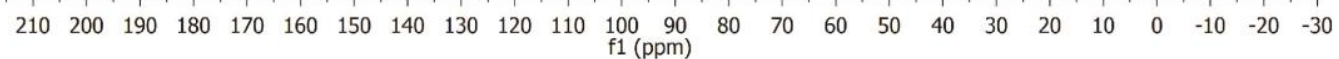

Figure S14. ${ }^{13} \mathrm{C}$ NMR spectrum of 32TEG: TEG/Decane Block 32mer in $\mathrm{CDCl}_{3}$

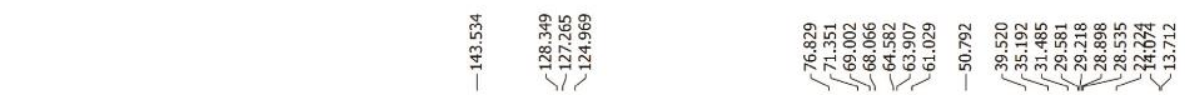

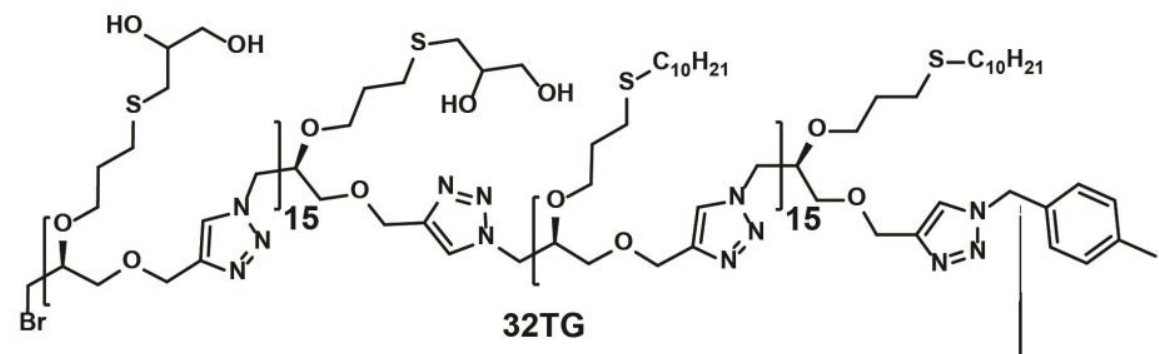

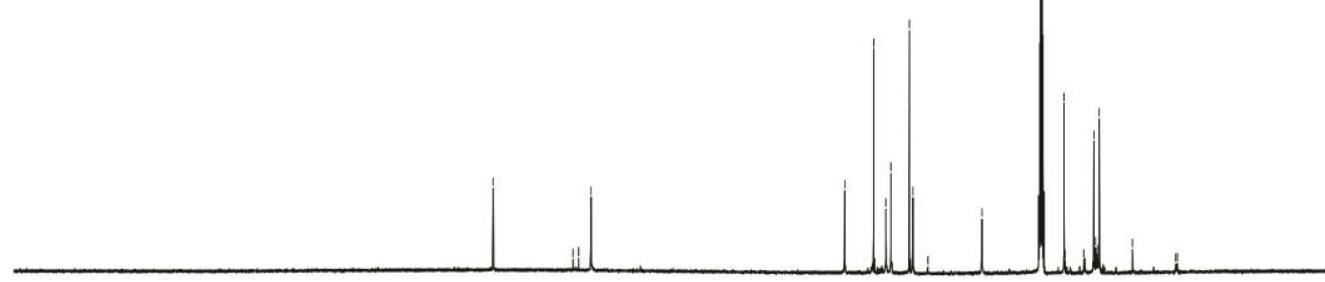

$\begin{array}{llllllllllllllllllllllllll}230 & 220 & 210 & 200 & 190 & 180 & 170 & 160 & 150 & 140 & 130 & 120 & 110 & 100 & 90 & 80 & 70 & 60 & 50 & 40 & 30 & 20 & 10 & 0 & -10\end{array}$

Figure S15. ${ }^{13} \mathrm{C}$ NMR spectrum of 32TG: TG/Decane Block 32mer in $\left(\mathrm{CD}_{3}\right)_{2} \mathrm{SO}$ 


\section{Section D. Spectrometric Characterization}

Matrix-Assisted Laser Desorption/Ionization Time-of-Flight Mass Spectrometry (MALDI-TOF-MS)

a) 4,8 , and 16
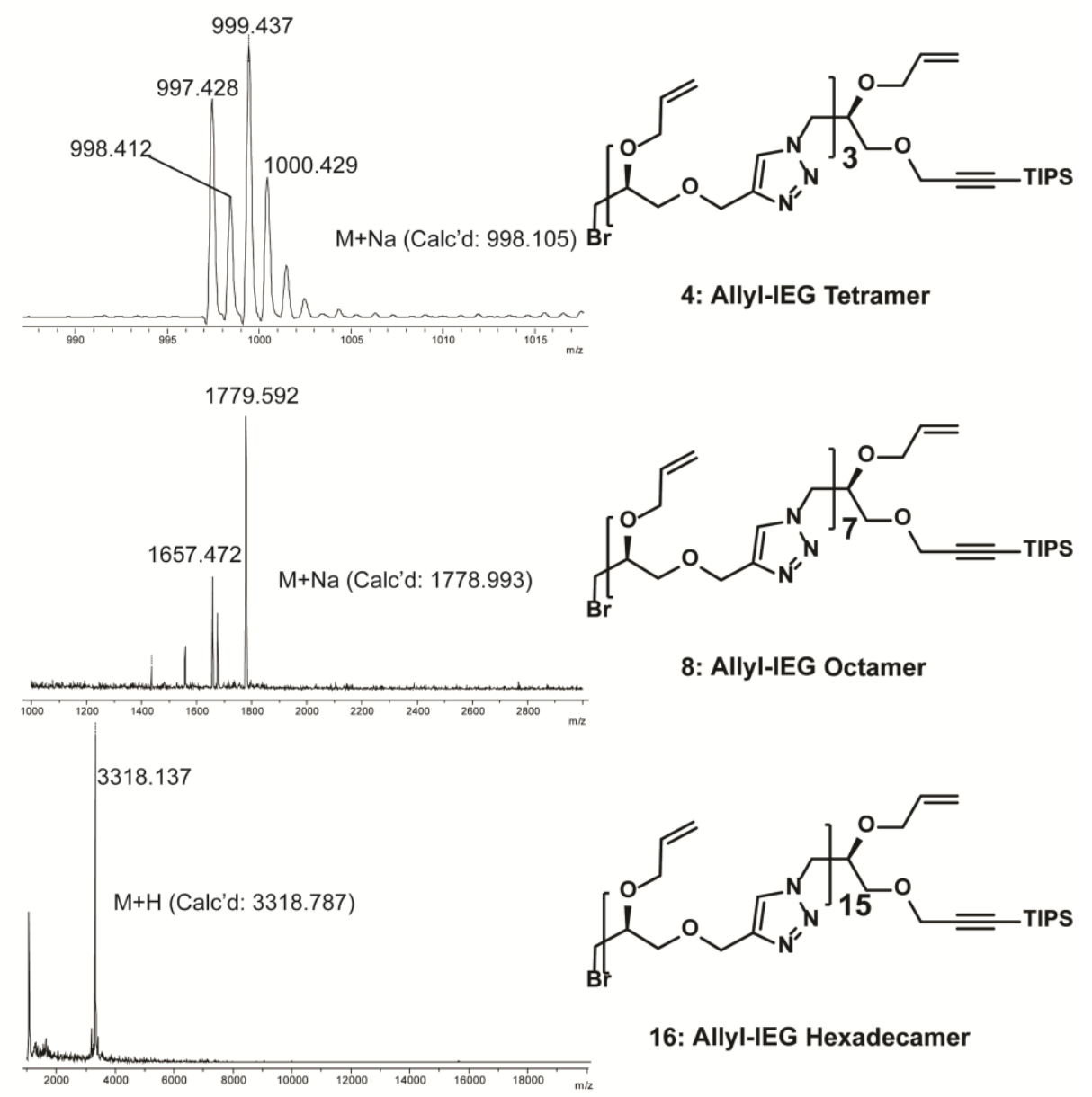

Figure S16. Stacked MALDI spectra for Allyl-IEG oligomers 4, 8, and 16. 
b) 32a, 32TEG, and 32TG
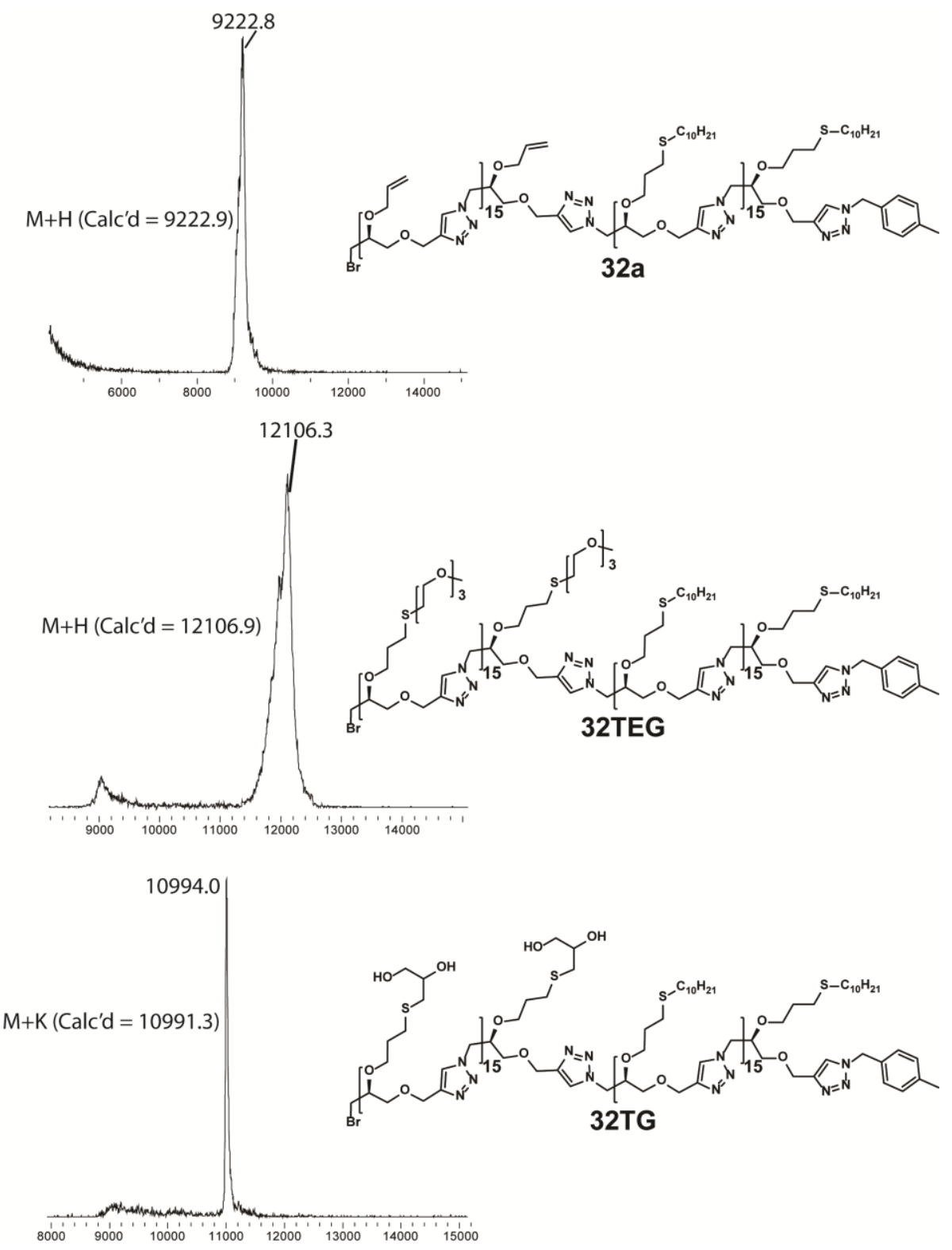

Figure S17. Stacked MALDI spectra for IEG block copolymers 32a, 32TEG, and 32TG. 
Section E. Extended Gel Permeation Chromatography Traces

a) $2,4,8$, and 16

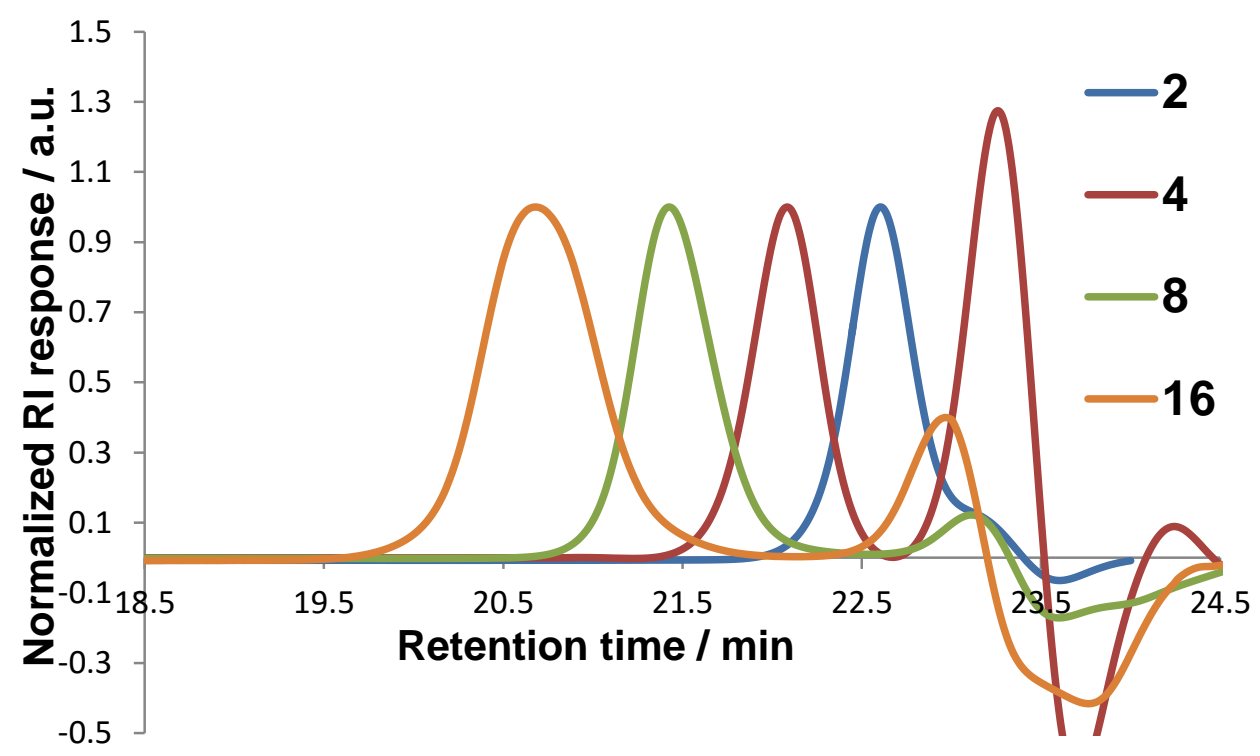

Figure S18. Extended GPC traces of Allyl-IEG oligomers 2, 4, 8, and 16.

b) 32a and 32TEG

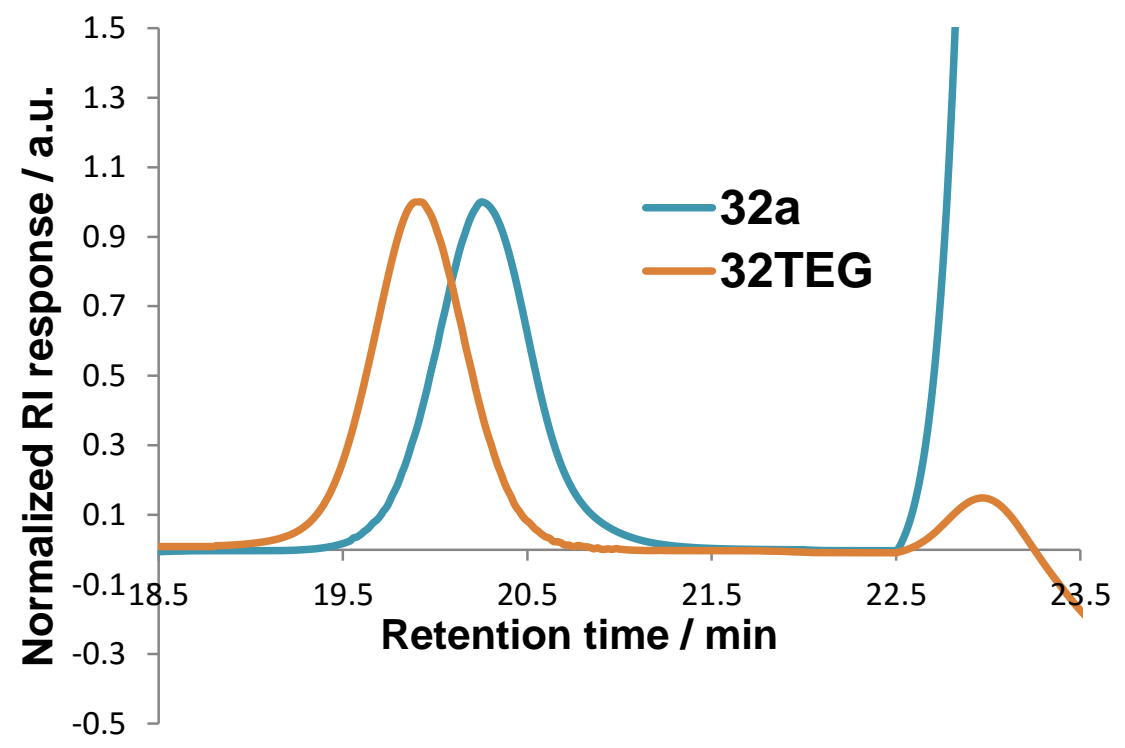

Figure S19. Extended GPC traces of IEG block copolymers 32a and 32TEG. 
c) 32TG

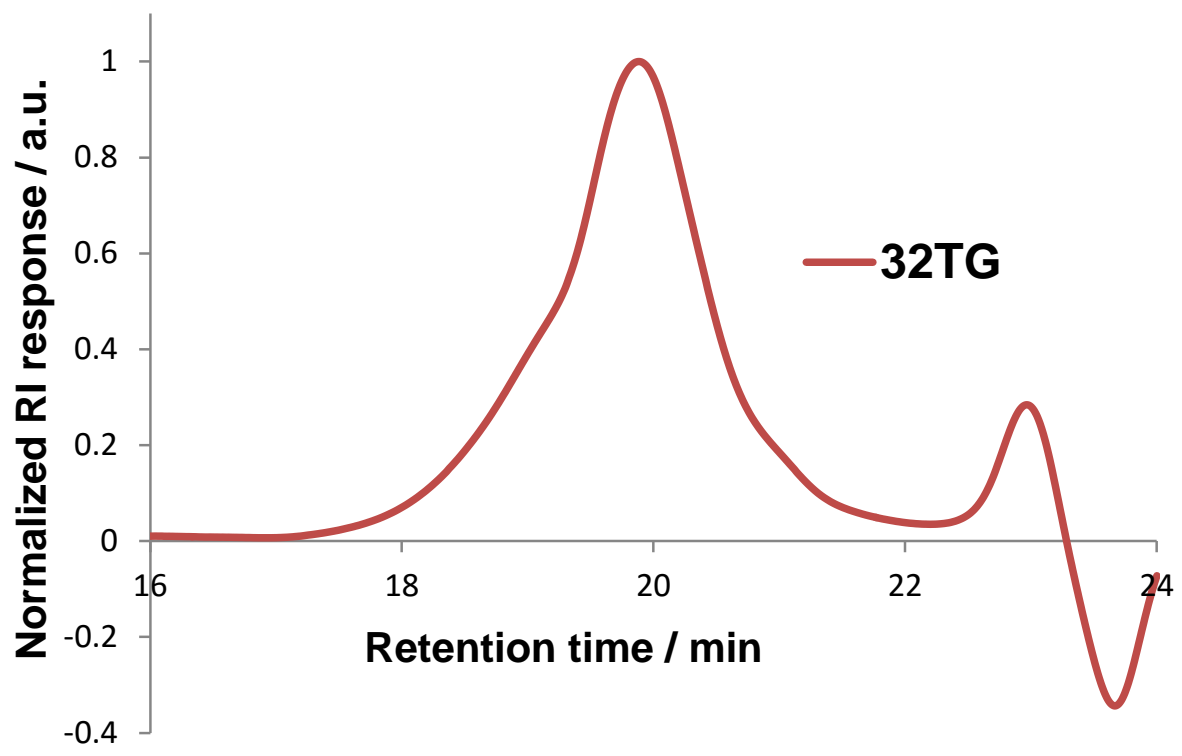

Figure S20. Extended GPC trace of IEG block copolymer 32TG.

d) Acetyl32TG

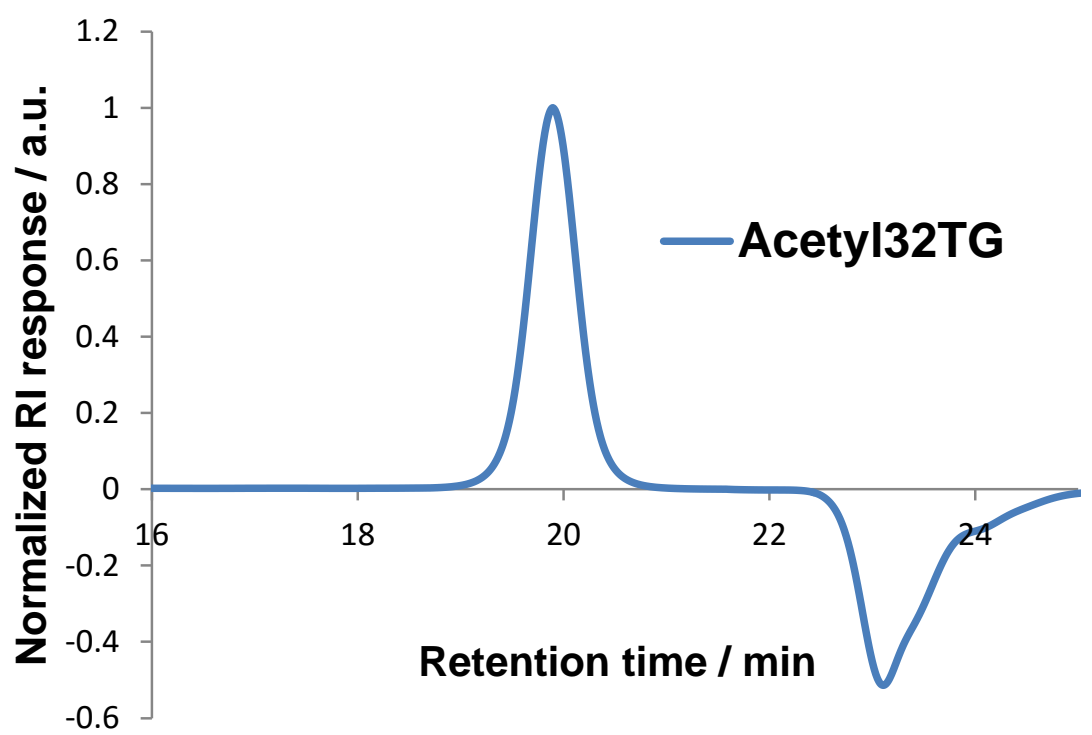

Figure S21. Extended GPC trace of IEG block copolymer Acetyl32TG. 
Section F. Thermal Characterization

A

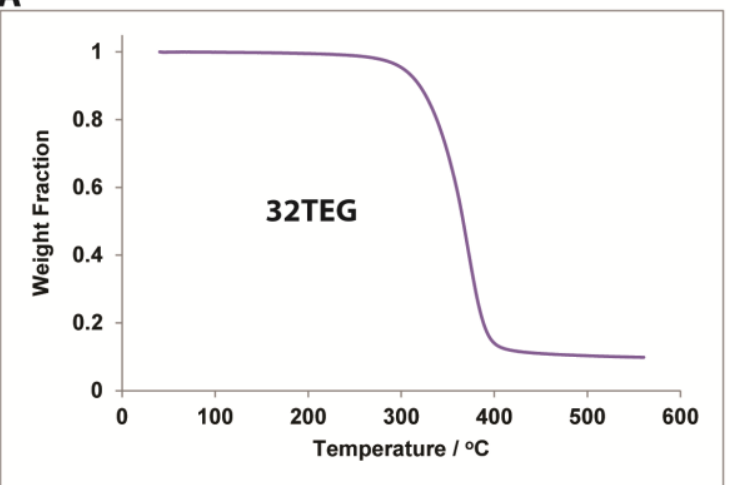

C

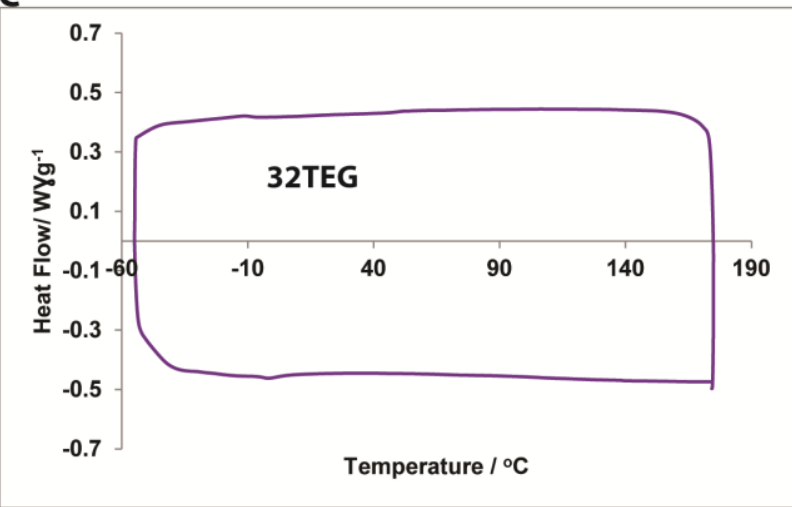

B

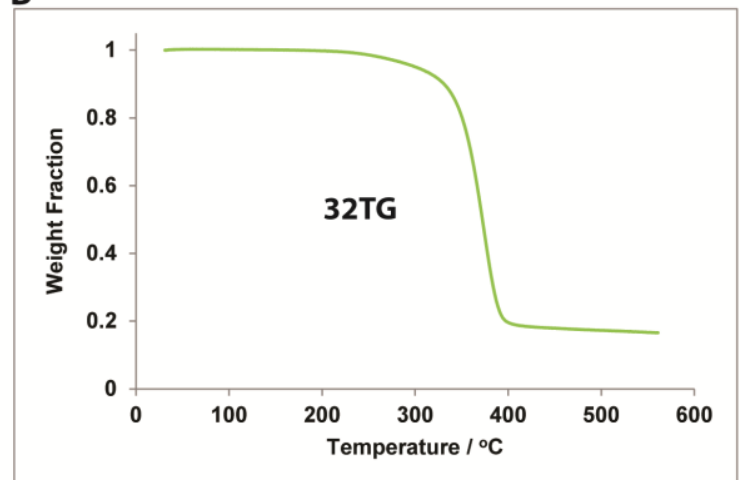

D

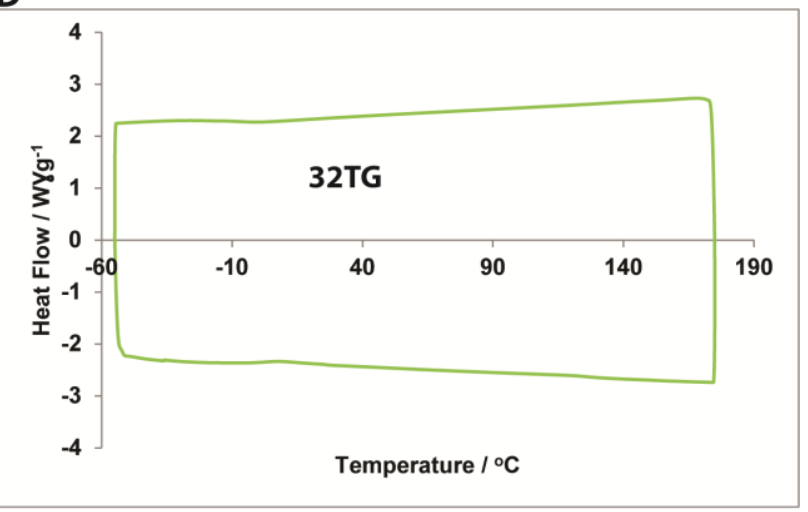

Figure S22. (A) TGA trace of 32TEG. 5\% weight loss occurs at $302{ }^{\circ} \mathrm{C}$. (B) TGA trace of 32TG. 5\% weight loss occurs at $301{ }^{\circ} \mathrm{C}$. (C) DSC trace of 32TEG. $\mathrm{T}_{\mathrm{g}}$ can be observed at $1{ }^{\circ} \mathrm{C}$. (D) DSC trace of 32TG. $\mathrm{T}_{\mathrm{g}}$ can be observed at $12{ }^{\circ} \mathrm{C}$. 
Section G. Chimera Distance Estimation

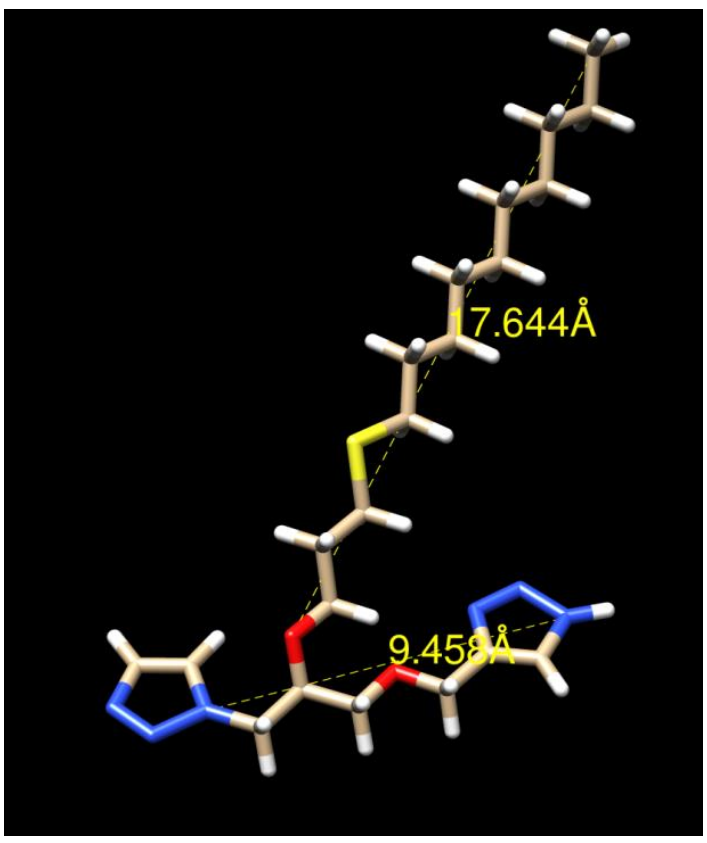

Figure S23. Measurements of a fully extended monomer unit in the Chimera software ${ }^{2}$ gives a length of 9.457 angstroms for each monomer residue and a length of 17.644 angstroms for the full decane based sidechain.

\section{Section H. References}

1. Keddie, D. J.; Grande, J. B.; Gonzaga, F.; Brook, M. A.; Dargaville, T. R. Org. Lett. 2011, 13, 6006.

2. Pettersen E.F.; Goddard T.D.; Huang C.C.; Couch G.S.; Greenblatt D.M.; Meng E.C.; Ferrin T.E.; J. Comput. Chem. 2004, 13, 1605. 